\title{
Sensitivity studies of oxidative changes in the troposphere in 2100 using the GISS GCM
}

\author{
J. L. Grenfell ${ }^{1,2}$, D. T. Shindell ${ }^{1}$, and V. Grewe ${ }^{1,3}$ \\ ${ }^{1}$ NASA Goddard Institute for Space Studies and Center for Climate Systems Research, Columbia University, New York, USA \\ ${ }^{2}$ Present address: Stratosphärengruppe, Institut für Meteorologie, Freie Universität Berlin, Germany \\ ${ }^{3}$ Present address: DLR-Institut für Physik der Atmosphäre, DLR Oberpfaffenhofen, Germany
}

Received: 10 January 2003 - Published in Atmos. Chem. Phys. Discuss.: 1 April 2003

Revised: 23 June 2003 - Accepted: 8 July 2003 - Published: 3 September 2003

\begin{abstract}
We examine the relative importance of chemical precursor emissions affecting ozone $\left(\mathrm{O}_{3}\right)$ and hydroxyl $(\mathrm{OH})$ for the year 2100. Runs were developed from the Comparison of Tropospheric Oxidants (Ox_Comp) modeling workshop year $2100 \mathrm{~A} 2 \mathrm{p}$ emissions scenario, part of the Intergovernmental Panel on Climate Change (IPCC) third assessment report (TAR). While TAR examined only cumulative change, we examine individual components $\left(\mathrm{NO}_{\mathrm{x}}\right.$, $\mathrm{CH}_{4}$, $\mathrm{CO}$, etc.). Also, since there will be climate changes in 2100 (not accounted for by TAR), we investigate the effect of changing our fixed SSTs/ocean ice from present day to 2100 conditions, as projected by a coupled oceanatmosphere model with doubled $\mathrm{CO}_{2}$. Unlike TAR we perform multiannual integrations and we include interactive lightning. Largest changes arose from the run with 2100 industrial $\mathrm{NO}_{\mathrm{x}}\left(\mathrm{O}_{3}=+16.9 \%, \mathrm{OH}=+29.4 \%\right.$ in July $)$ and the run with 2100 methane $\left(\mathrm{O}_{3}=+17.4 \%, \mathrm{OH}=-19.1 \%\right.$ in July). In the latter run, large ozone increases in the NH upper troposphere appeared to repartition $\mathrm{HO}_{2}$ into $\mathrm{OH}$ to such an extent that the lowering in $\mathrm{OH}$ associated with increased methane was overwhelmed in that region. Incorporating all changes collectively led to the July tropospheric ozone burden increasing from 426 to $601 \mathrm{Tg}(+41.1 \%)$ and the July $\mathrm{OH}$ concentration increasing from 13.6 to $15.2 \times 10^{5}$ molecules $/ \mathrm{cm}^{3}$ $(+11.8 \%)$.
\end{abstract}

\section{Introduction}

Accurately predicting oxidative and associated radiative changes occurring in the troposphere over the coming century is extremely difficult. The major oxidants ozone $\left(\mathrm{O}_{3}\right)$ and hydroxyl $(\mathrm{OH})$ are not emitted directly into the atmosphere and their concentrations are determined by complex

Correspondence to: J. L. Grenfell

(grenfell@strat01.met.fu-berlin.de) interplay between dynamics and chemistry which is a function of $\mathrm{NO}_{\mathrm{x}}$ (defined here as $\left[\mathrm{NO}+\mathrm{NO}_{2}+\mathrm{NO}_{3}\right]$ ), $\mathrm{CO}, \mathrm{H}_{2} \mathrm{O}$ and hydrocarbons. $\mathrm{NO}_{\mathrm{x}}$ emissions from aircraft, lightning, soil and stratospheric input are subject to uncertainty. Model estimates of the impact of individual sources to the atmospheric $\mathrm{NO}_{\mathrm{x}}$ concentration show even qualitatively a wide range (Grewe et al., 2001a). Ozone in the troposphere is formed from $\mathrm{NO}_{2}$ in the presence of hydrocarbons and $\mathrm{CO}$ and is destroyed by dry deposition and chemical sinks. It has a short turnover time (days to weeks) and its concentration varies markedly with altitude near the tropopause, where radiative forcing sensitivities are largest . $\mathrm{OH}$ is formed by ozone photolysis in the presence of water vapor and is destroyed mainly by reaction with $\mathrm{CO}, \mathrm{NO}_{2}$ and $\mathrm{CH}_{4}$. It is the main chemical sink for methane and contributes, along with aqueous-phase chemistry to the oxidation of $\mathrm{SO}_{2}$ into sulfate. Its local concentration can be measured with reasonable confidence (e.g. Poppe et al., 1994) and its global mean derived indirectly e.g. from methyl chloroform measurements (Prinn et al., 1995) but direct observations of its global distribution are lacking.

The model employed here has been extensively validated (Shindell et al., 2001) and was found to simulate present conditions satisfactorily. The model's greatest deficiency is an overestimate of the flux of ozone from the stratosphere to the troposphere due to the limited vertical resolution. Nonmethane hydrocarbons (NMHCs) are not directly included in our chemistry scheme although we do include a $\mathrm{CO}$ proxy for isoprene. Roelofs and Lelieveld, (2000) found that including NMHCs in a present-day simulation led to a $8 \%$ increase in $\mathrm{O}_{3}$ and a $8 \%$ decrease in $\mathrm{OH}$. Wang et al. (1998) found $<15 \%$ more $\mathrm{O}_{3}$ (mainly in the remote troposphere) and $20 \%$ less OH (mainly in NH summer). Trainer et al. (1993) concluded that $\mathrm{O}_{3}$ is more often limited by $\mathrm{NO}_{\mathrm{x}}$ rather than hydrocarbons.

There have been numerous recent model studies of future chemistry-climate interaction in the troposphere. Collins et 
al. (2000) simulated present-day and 2100 conditions with a CTM and found a 1.48 increase in the tropospheric ozone burden and a decrease by 0.79 in the turnover time. Stevenson et al. (2000) used a revised version of the same CTM and found a 1.32 and 1.49 increase in the ozone burden for runs with and without climate (defined here as temperature and humidity) change. Grewe et al. (2001b) simulated present day and 2015 conditions and noted the importance of coupling chemistry with precipitation changes, especially in the tropics. The Ox_Comp comparison (IPCC TAR, Sect. 4; Prather et al., 2003) compared projected (2100) $\mathrm{O}_{3}$ and $\mathrm{OH}$ for fourteen models, including the GISS GCM. All produced comparable mean increases in the overall tropospheric $\mathrm{O}_{3}$ burden but disagreed in the zonal mean. This was attributed mainly to differences in the transport schemes.

The response of the large-scale circulation to future climate change has been extensively investigated (Rind, 1998; Bengtsson et al., 1996; Ramstein et al., 1998; IPCC, 1996). Most models predict a weaker latitudinal gradient in surface temperature with associated weaker Hadley cell intensity, reduced surface winds, eddy transports and a smaller wavelength of maximum baroclinic instability. We present results for our model in Sect. 4. Section 2 provides a model description; Sect. 3 an overview of the runs; Sect. 4, results; Sect. 5, conclusions and future work.

\section{Model description}

A full description may be found in Hansen et al. (1983), Hansen et al. (1997) and Shindell et al. (2001). Briefly, we use a version of the Goddard Institute for Space Studies (GISS) general circulation model (GCM) having 72 longitudes and 46 latitudes $\left(\sim 4 \times 5^{\circ}\right)$ horizontal resolution and 9 sigma levels in the vertical. The model used in this study has only a very limited stratosphere (two stratospheric levels with a dynamical lid at $10 \mathrm{hPa}$ ). Climatological (monthly) sea surface temperatures (SSTs) and ocean ice were fixed, so the model is not fully interactive.

The present day ocean (SSTs and ocean ice) was based on the AMIP (atmospheric modeling intercomparison project) 1979-1993 means. The "2100 ocean" ( prescribed SST and ocean ice conditions) was taken from the last 20 years of a previous 50 year equilibrium integration of the GCM with doubled $\mathrm{CO}_{2}$ and which used prescribed rates of ocean heat fluxes (the qflux scheme) (Hansen et al., 1983; Russell et al., 1985). A full analysis of this run is not the aim of this paper. It was used only as a tool to obtain an estimate of future climate conditions. Largest differences in (21002000) sea surface temperatures (SSTs) of $3-4^{\circ} \mathrm{C}$ occurred in far southern regions and in the north Atlantic. The global mean increase was $2.6^{\circ} \mathrm{C}$. Incorporating 2100 ocean ice coverage led to a mean decrease in the global, annual mean from $4.38(\mathrm{NH}=4.28, \mathrm{SH}=4.48)$ to $3.13(\mathrm{NH}=3.45, \mathrm{SH}=2.81) \mathrm{kg}$ ice $/ \mathrm{m}^{2}$.
Convection is calculated via adiabatic adjustment (Del Genio and Yao, 1993). We employ 9 chemical tracers using the "family" approach. There are 37 reactions for 24 molecules based on the Jet Propulsion Laboratory (JPL) 1997 kinetic data. No peroxy acetyl nitrate (PAN) or explicit NMHC chemistry is employed. The fastj photolysis scheme is used to calculate 14 photolysis reaction rates (Wild et al., 2000). The chemical timestep is $1 \mathrm{~h}$ whereas the dynamical timestep is 5 minutes. $\mathrm{N}_{2} \mathrm{O}_{5}$ hydrolysis (Dentener and Crutzen, 1993) on sulfate aerosol (Koch et al., 1999) is included. Wet and dry deposition are parametrized. An interactive cloud-lightning scheme is used to generate $\mathrm{NO}_{\mathrm{x}}$ (Price et al., 1997). Emissions include $\mathrm{NO}_{\mathrm{x}}$ (industrial, aircraft and soil) and $\mathrm{CO}$ (biomass burning, equivalent isoprene and industrial). Methane $\left(\mathrm{CH}_{4}\right)$, carbon dioxide $\left(\mathrm{CO}_{2}\right)$ and nitrous oxide $\left(\mathrm{N}_{2} \mathrm{O}\right)$ are set to prescribed values for each run. Ox burdens in the troposphere were calculated using an analysis technique based on the ozone mixing ratio, in which we defined the stratosphere as those gridboxes having greater than $150 \mathrm{ppbv}$ ozone. This correlates reasonably well with the location of the meteorological tropopause, though the resolution in this region is not sufficient to simulate this well.

\section{Overview of runs}

We have performed present day (2000) and future (2100) simulations. Additionally, the relative simplicity of our chemical scheme enabled a large number (10) of sensitivity runs to be performed which quantified the effect of individual perturbations (Table 1), e.g. changing industrial $\mathrm{NO}_{\mathrm{x}}, \mathrm{CO}$ etc. All runs were ten years in duration (including a 2-year spin-up which was discarded). This expands upon the TAR studies in which models were run for only two years. All figures show eight year January and July average model output unless otherwise stated. The simulations were performed with a feedback of chemical species $\left(\mathrm{O}_{3}, \mathrm{CH}_{4}\right)$ to the radiation so that changes in the chemical composition affected the dynamics (hence dynamical stability, cloud cover, lightning $\mathrm{NO}_{\mathrm{x}}$ emissions, washout etc.) and vice-versa.

The Ox_Comp workshop examined the effect of future emissions by performing an intercomparison of model runs for the year 2100. Relative to the control run, the year 2100 run changed $\mathrm{CH}_{4}$ from 1745 to 4300 ppbv; $\mathrm{N}_{2} \mathrm{O}$ from 314 to $455 \mathrm{ppbv}$ and $\mathrm{CO}_{2}$ from 365 to $891 \mathrm{ppbv}$. For our control run, 1992 aircraft emissions data based on Baughcum et al. (1996) were scaled up by $37 \%$ ( $=4.6 \% / y e a r)$ to reflect the increase from 1992 to 2000. For a review of the other GISS GCM source inventories used in the control run see Shindell et al. (2001).

The 2100 run was based on the IPCC A2 (IS92a) marker scenario for which emissions increased the most and population changed from six to fifteen billion. The projected emission data are more fully documented in the IPCC 2000 TAR Sect. 4. Rapid industrialized growth is assumed to 
Table 1. Description of the ten runs with associated $\mathrm{OH}$ and ozone concentrations. OH values are global means $\left(1 \times 10^{5} \mathrm{molecules} \mathrm{cm}^{3}\right)$ whereas ozone values represent total tropospheric burdens (Tg). Values in brackets for run one represent $95 \%$ confidence intervals. Runs eight and nine are stand-alone runs whereas all other runs combine to form run ten

\begin{tabular}{|c|c|c|c|c|c|}
\hline Run & Description & $\mathrm{OH}(\mathrm{Jan})$ & $\mathrm{OH}(\mathrm{Jul})$ & Ozone (Jan) & Ozone (Jul) \\
\hline 1 & Control (year 2000) & $5.6(0.1)$ & $13.6(0.2)$ & $403(5.2)$ & $426(5.0)$ \\
\hline 2 & 2100 industrial CO & 5.1 & 13.0 & 407 & 426 \\
\hline 3 & $2100 \mathrm{NO}_{\mathrm{X}}$ fossil fuel & 7.4 & 17.6 & 471 & 502 \\
\hline 4 & $2100 \mathrm{CH}_{4}=4300 \mathrm{ppbv}$ & 4.6 & 11.0 & 464 & 500 \\
\hline 5 & 2100 NMHCs & 5.3 & 13.1 & 425 & 425 \\
\hline 6 & 2100 ocean & 6.1 & 14.8 & 412 & 420 \\
\hline 7 & 2100 aircraft $(1992 * 4.34)$ & 5.7 & 14.0 & 406 & 426 \\
\hline 8 & Control but with $1.1 \mathrm{CH}_{4}$ & 5.4 & 13.3 & 407 & 426 \\
\hline 9 & $\begin{array}{l}\text { All } 2100 \text { changes except } \\
\mathrm{NO}_{\mathrm{x}} \text { fossil fuel }\end{array}$ & 4.7 & 11.4 & 490 & 513 \\
\hline 10 & All 2100 changes & 6.1 & 15.2 & 574 & 601 \\
\hline
\end{tabular}

occur over Asia (and parts of Africa) where emissions increase by $\sim 4 \%$ per year (Kato and Akimoto, 1992). CO and $\mathrm{NO}_{\mathrm{x}}$ emissions over North America and Europe stabilize or decline slightly by 2100 . Emissions of industrial $\mathrm{NO}_{\mathrm{x}}$ were $108.9 \mathrm{Tg} /$ year and of industrial $\mathrm{CO}$ were $2486 \mathrm{Tg} /$ year. We also adopted the 2100 recommended Ox_Comp $\mathrm{NO}_{\mathrm{x}}$ aircraft emissions of Baughcum et al. (1996) scaled up by a factor of 4.34. Parameterizing 2100 NMHCs was challenging since these compounds were not explicitly included in our chemistry scheme. Discussions within Ox_Comp suggested a doubling in the NMHC burden by 2100 . After our runs were completed this factor was revised to 2.3 (TAR, p. $269 ; 150$ to $350 \mathrm{Tg} \mathrm{CO} /$ year from 2000 to 2100 ) but we believe this does not greatly affect the results. As a sensitivity test, we chose to double $\mathrm{CO}$ emissions arising from isoprene (to $290 \mathrm{Tg} \mathrm{CO} /$ year). We used this approach because isoprene dominates the NMHC budget (TAR, p. 258, Table 4.7A) and its CO proxy was already present in our model. The 2100 NMHC distribution was also problematic. The introduction of agroforests in the tropics with associated fastgrowing species favored by e.g. the rubber and timber industries suggests increased isoprene emissions whereas in other regions conversion to pasture land will tend to have the opposite effect; also, industrialization clearly favours emissions of anthropogenic rather than biogenic hydrocarbons. Climate change effects will also influence growing rates, speciation hence biogenic emissions. The overall effect is unclear (TAR 4.3.3). Ox_Comp chose not to recommend any particular future NMHC distribution. We therefore chose to retain our present-day isoprene distribution. Further details of the assumptions we make in deriving $\mathrm{CO}$ from isoprene emissions may be found in Shindell et al. (2001). The efficiency of conversion of isoprene into $\mathrm{CO}$ is uncertain, which should be bourne in mind when we discuss the $\mathrm{HCHO}$ response. In this paper we investigate the individual effect upon ozone and $\mathrm{OH}$ of each projected change for 2100 conditions (i.e. individual
GHG, individual source inventory shift) relative to the year 2000 run. Table 1 summarizes the ten runs performed. Run 6 investigated the effect of changing from a present day to a 2100 ocean (SSTs and ocean ice) using output from a simple model of ocean heat storage (the qflux scheme) (further information is provided in Sect. 2) with doubled $\mathrm{CO}_{2}$. Run 10 investigated the combined effect of all changes. We have also performed some stand-alone runs which were suggested (but not strictly required) for Ox_Comp. These included modifying the control with a $10 \%$ increase in methane (run 8) and a run having all 2100 changes except $\mathrm{NO}_{\mathrm{x}}$ fossil fuel (run 9). The latter was intended to estimate amongst other things how well the oxidative capacity of the troposphere would fare without the positive influence of a projected $\mathrm{NO}_{\mathrm{x}}$ increase (which tends to increase $\mathrm{OH}$ ).

\section{Results}

Table 1 gives a brief description of the runs and shows January/July tropospheric $\mathrm{O}_{3}$ and global $\mathrm{OH}$ concentrations for the ten runs. Table 2 shows 95\% confidence intervals for ozone and hydroxyl (control run) in the lower, central and upper troposphere at low, mid and high latitudes. Table 3 shows global changes of chemical tracers in July for all runs. An important point to realise is, the runs performed here are complementary to the TAR report, and expand upon it in the ways discussed previously. Like the other models in TAR, the GISS model employs fixed SSTs. Naturally the model cannot therefore respond fully on the lower levels. This point should always be bourne in mind, especially where we discuss physical responses of the model e.g changes in the meridional circulation and cloudiness. There are numerous climate studies that also discuss the response of such phenomena, and which are not limited by the fixed SST constraint. It is the aim of this paper to complement and build- 
Table 2. 95\% confidence intervals in the control run in January and July for ozone (ppbv) and hydroxyl $\left(1 \times 10^{5}\right.$ molecules $\left./ \mathrm{cm}^{3}\right)$ on model levels $1(959 \mathrm{mb}), 3(787 \mathrm{mb})$ and $6(323 \mathrm{mb})$ output on gridboxes close to the equator $\left(2^{\circ} \mathrm{N}\right)$, mid latitudes $\left(42^{\circ} \mathrm{N}\right)$ and the north pole

\begin{tabular}{cccccccc}
\hline Month & Level & Equator & $\begin{array}{c}\text { Ozone } \\
\text { Mid-latitude }\end{array}$ & Pole & Equator & $\begin{array}{c}\text { Hydroxyl } \\
\text { Mid-latidude }\end{array}$ & Pole \\
\hline \multirow{3}{*}{ January } & 6 & 0.74 & 1.07 & 3.51 & 7.55 & 5.63 & 0.1 \\
& 3 & 0.93 & 0.1 & 1.67 & 3.51 & 5.73 & 0.1 \\
& 1 & 0.1 & 0.1 & 3.55 & 6.68 & 4.83 & 0.1 \\
\multirow{5}{*}{ July } & 6 & 0.93 & 1.04 & 13.26 & 15.41 & 16.45 & 2.12 \\
& 3 & 0.93 & 1.04 & 5.55 & 5.44 & 8.75 & 0.71 \\
& 1 & 0.1 & 0.93 & 0.93 & 10.31 & 13.85 & 2.62 \\
\hline
\end{tabular}

Table 3. Global average July concentrations for chemical tracers in the GISS model. Concentrations are in pptv except CO which is in ppbv. For brevity, we show only July values (which generally featured a larger chemical response compared with January). The various sensitivity runs are explained in more detail in Table 1 . The $95 \%$ confidence interval for the control run is shown in brackets

\begin{tabular}{lccccccc}
\hline Run & $\mathrm{NO}_{\mathrm{x}}$ & $\mathrm{HNO}_{3}$ & $\mathrm{H}_{2} \mathrm{O}_{2}$ & $\mathrm{CH}_{3} \mathrm{OOH}$ & $\mathrm{HCHO}$ & $\mathrm{HNO}_{4}$ & $\mathrm{CO}$ \\
\hline Control & $362(0.9)$ & $1616(13.0)$ & $1066(17.9)$ & $249(2.1)$ & $152(2.1)$ & $24.5(0.5)$ & $65(1.1)$ \\
$\mathrm{CO}$ & 363 & 1616 & 1178 & 251 & 148 & 26 & 78 \\
$\mathrm{NO}_{\mathrm{x}}$ & 444 & 2200 & 993 & 223 & 211 & 29 & 63 \\
$\mathrm{CH}_{4}$ & 351 & 1635 & 1449 & 613 & 309 & 33 & 115 \\
$\mathrm{NMHC}$ & 362 & 1612 & 1153 & 250 & 148 & 25 & 75 \\
Ocean & 361 & 1646 & 1295 & 291 & 171 & 24 & 64 \\
Aircraft & 374 & 1673 & 1052 & 246 & 158 & 25 & 65 \\
$1.1 \mathrm{CH}_{4}$ & 361 & 1617 & 1099 & 276 & 163 & 25 & 69 \\
All- $_{\mathrm{NO}}$ & 355 & 1693 & 1970 & 721 & 346 & 34 & 137 \\
All & 446 & 2516 & 1840 & 667 & 487 & 44 & 131 \\
\hline
\end{tabular}

upon the results of TAR; specifically we wished to test the effect of climate change upon our interactive chemistry (response of washout rates, effect of increasing temperature etc.) and compare it with the effect of emission changes, which is why we performed the run with projected 2100 SST data (run 6). Long-term runs with both interactive chemistry and a coupled ocean are desirable but are not currently tenable.

\subsection{Control run}

The tropospheric ozone burden (Table 1) was slightly different from a previously published (Shindell et al., 2001) value due to differing aircraft emissions. The model has been shown by those authors to reproduce well both the global distribution of ozone, with lower values in the Southern Hemisphere compared with the Northern Hemisphere, and the seasonal cycle for the present day atmosphere. The global $\mathrm{OH}$ concentration of $9.6 \times 10^{5}$ molecules $/ \mathrm{cm}^{3}$ agreed well with the value of $9.7 \times 10^{5}$ derived by Prinn et al. (1995) using $\mathrm{CH}_{3} \mathrm{CCl}_{3}$ measurements made between 1978 and 1994. $\mathrm{OH}$ values in this work are mass-weighted. Lawrence et al., (2001) note that when comparing OH values with the Prinn result, it is more appropriate to weight the values by the rate of reaction of $\mathrm{OH}$ with methyl chloroform; this may change the result by up to $30 \%$. Table 4 shows our $\mathrm{OH}$ values for the 12 regions investigated by Lawrence et al. (2001). Our values compare well with the values shown in that work. Also, zonal mean height plots of ozone and $\mathrm{OH}$ for the control run (not shown) were found to be similar to other works (Hauglustaine et al., 1998; Mickley et al., 1999; Wang et al., 1998), except that we calculated $\sim 20 \%$ more ozone in $\mathrm{NH}$ summer. This results at least partially from excess influx from the stratosphere.

\subsection{Run 2 (2100 industrial CO)}

The tropospheric ozone burden increased only slightly (Table 1), and changes were small everywhere (Figs. 1a and b), which suggested that ozone production was mainly controlled by $\mathrm{NO}_{\mathrm{x}}$, rather than volatile organic compounds (VOCs) in the model. Of the other chemical tracers, only $\mathrm{CO}$ and $\mathrm{H}_{2} \mathrm{O}_{2}$ gave significant responses. $\mathrm{CO}$ increased by $50-100$ ppbv mainly in the tropics on all tropospheric levels and decreased by $50-100$ ppbv in $\mathrm{NH}$ mid-latitudes, consistent with the emissions scenario. $\mathrm{H}_{2} \mathrm{O}_{2}$ correspondingly increased by 500-800 pptv, again in the tropics and decreased by $100-150$ pptv in NH mid-latitudes, as increased 
(a) JAN RUN 2 (CO)

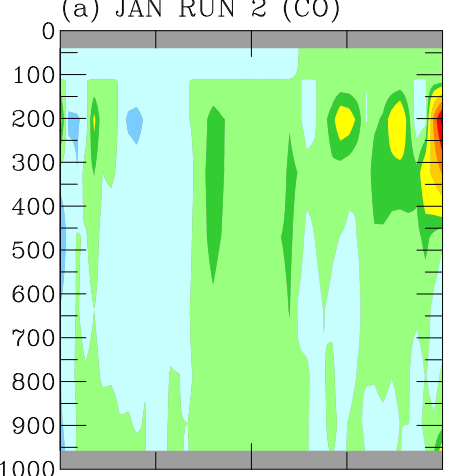

(d) JULY RUN 3 (NOx)
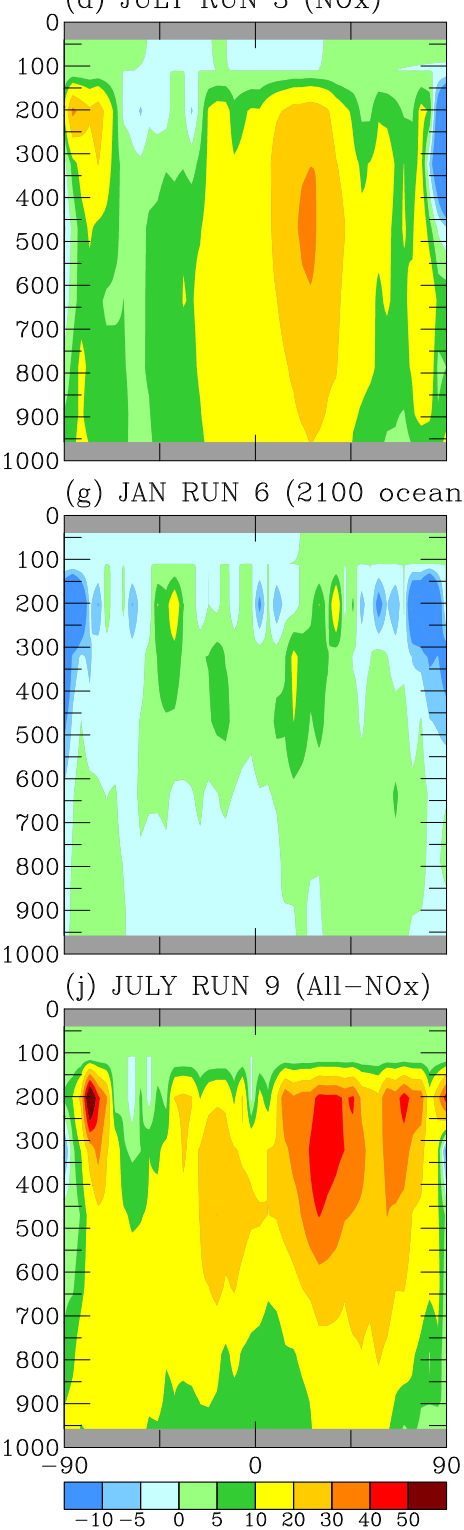

(b) JULY RUN 2 (CO)

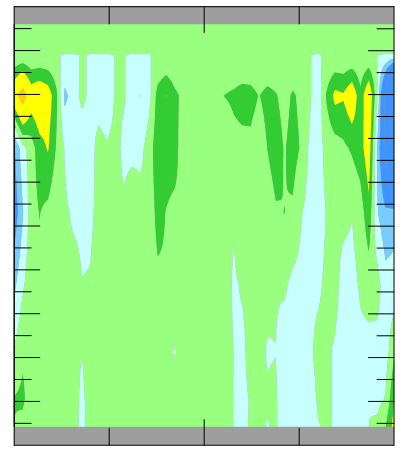

(e) JAN RUN 4 (CH4)

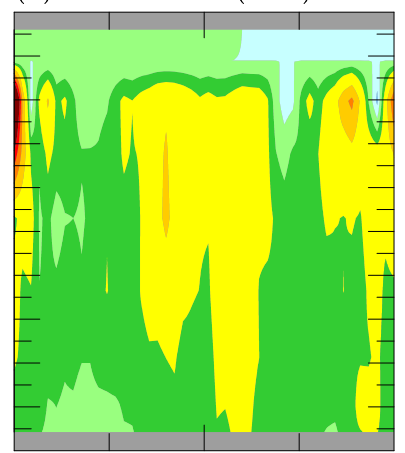

(h) JULY RUN 6 (2100 ocean)

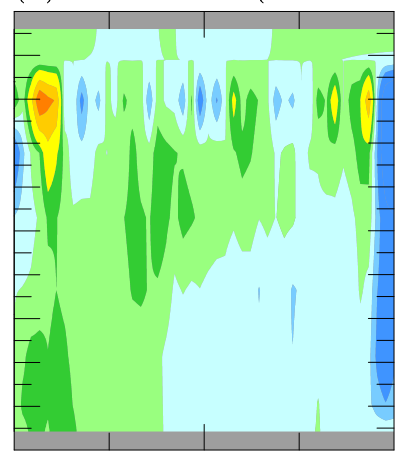

(k) JAN RUN 10 (All 2100)

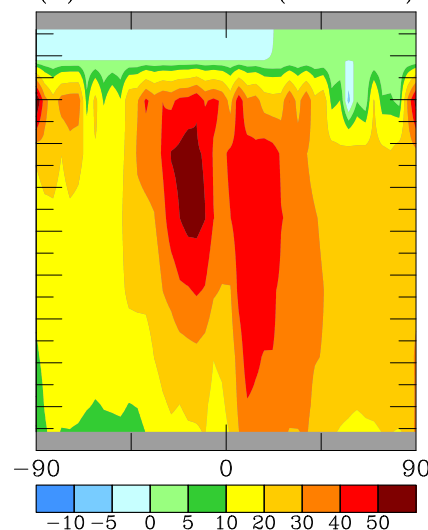

(c) JAN RUN 3 (NOx)

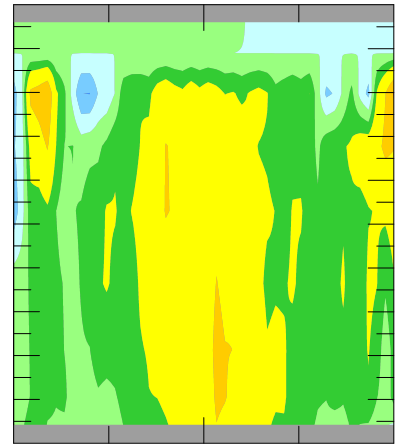

(f) JULY RUN 4 (CH4)

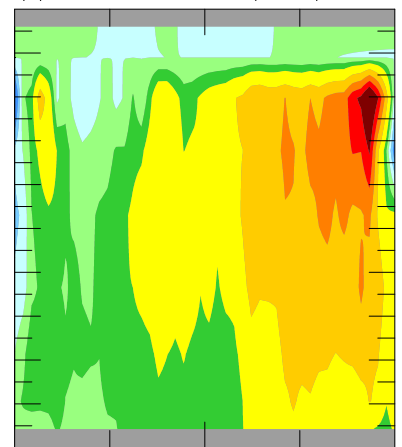

(i) JAN RUN 9 (All-NOx)

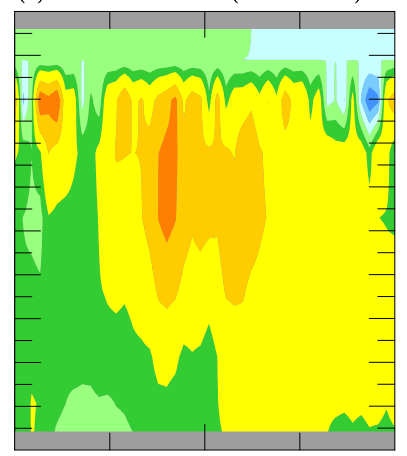

(1) JULY RUN 10 (All 2100)

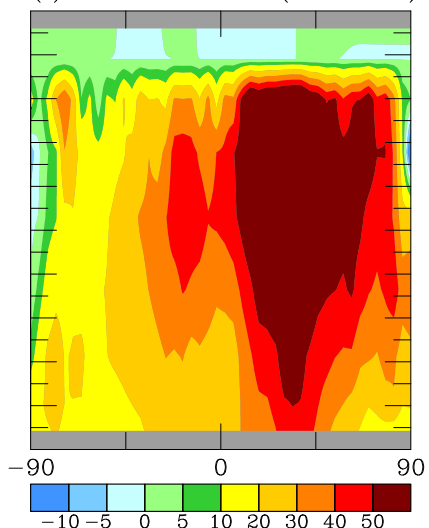

Fig. 1. Ozone change, (run $\mathrm{x}-$ control) (ppbv) in January and July for the $\mathrm{CO}, \mathrm{NO}_{\mathrm{x}}, \mathrm{CH}_{4}$, ocean, (all- $\mathrm{NO}_{\mathrm{x}}$ ) and all changes runs. The extremes of the color bar indicate all values less than -10 and greater than 50 . 
(a) JAN RUN 2 (CO)

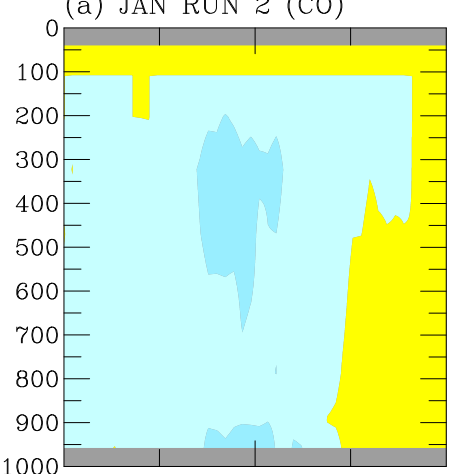

(d) JULY RUN 3 (NOx)

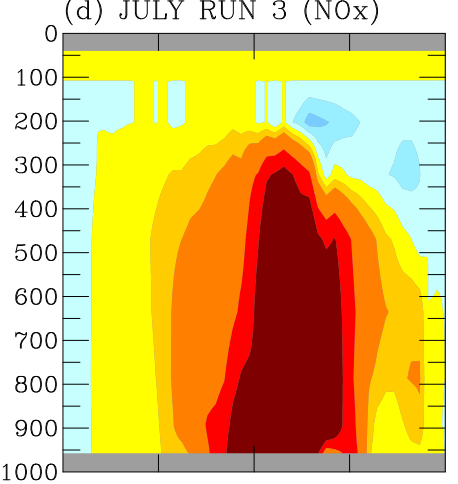

(g) JAN RUN 6 (2100 ocean)

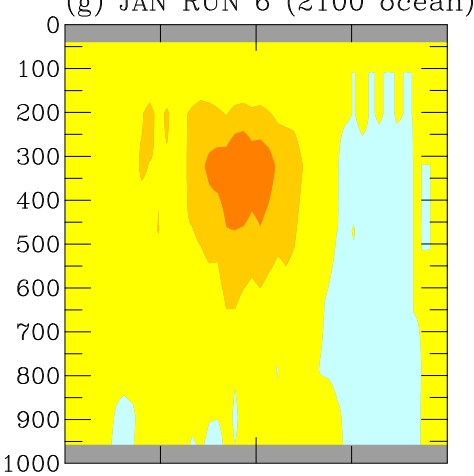

(j) JULY RUN 9 (All-NOx)

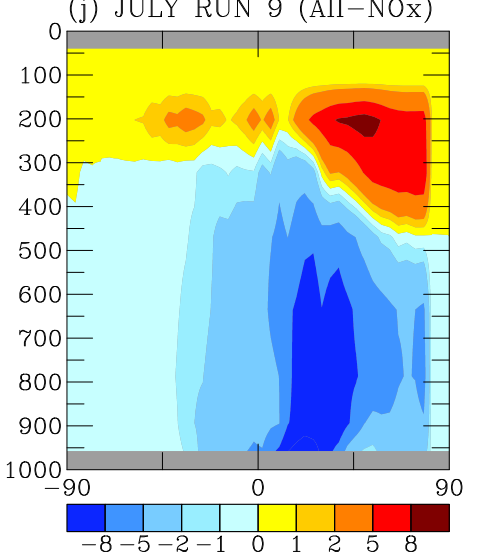

(b) JULY RUN 2 (CO)

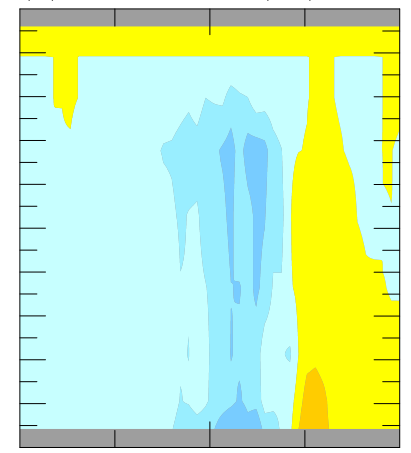

(e) JAN RUN 4 (CH4)

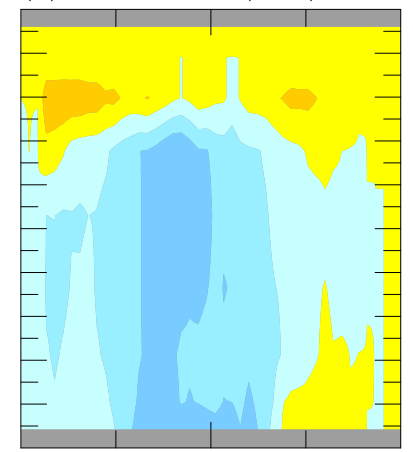

(h) JULY RUN 6 (2100 ocean)

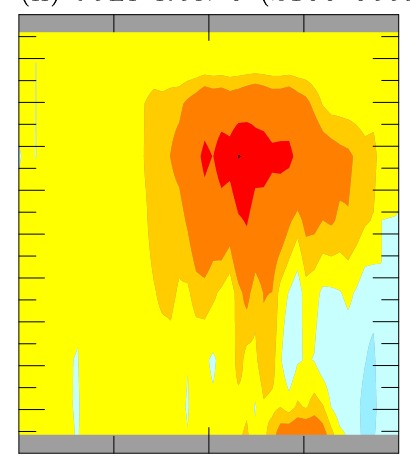

(k) JAN RUN 10 (All 2100)

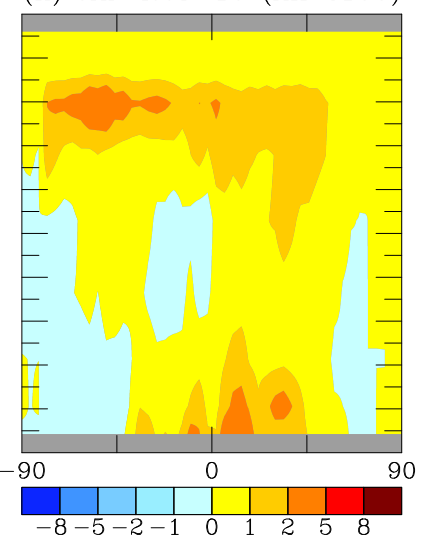

(c) JAN RUN 3 (NOx)

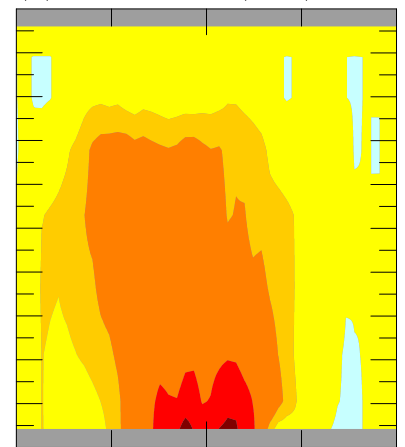

(f) JULY RUN 4 (CH4)

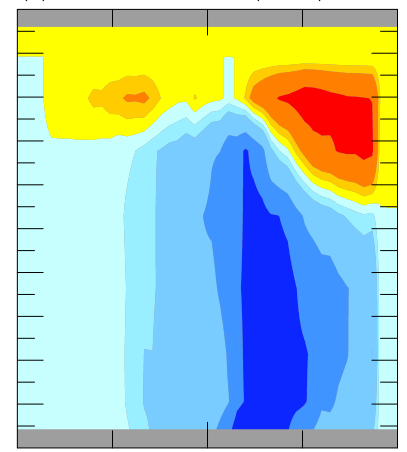

(i) JAN RUN $9(\mathrm{All}-\mathrm{NOx})$

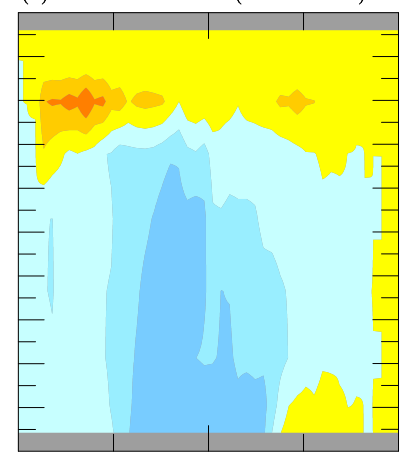

(1) JULY RUN 10 (All 2100)

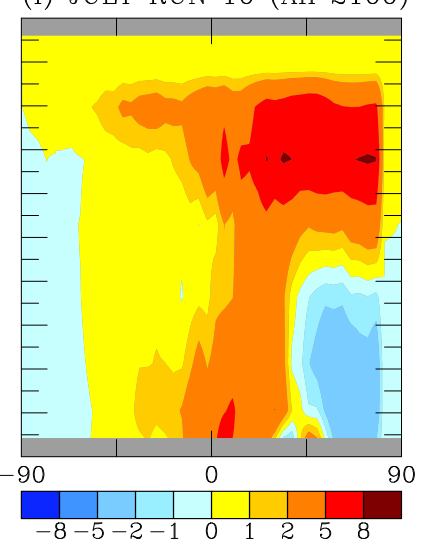

Fig. 2. Hydroxyl change, (run $\mathrm{x}-$ control) $\left(1 \times 10^{4}\right.$ molecules $\left./ \mathrm{cm}^{3}\right)$ in January and July for the same runs as Fig. 1 . The extremes ends of the color bar indicate all values beyond 8 . 
$\mathrm{CO}$ shifted the $\mathrm{OH} / \mathrm{HO}_{2}$ partitioning towards $\mathrm{HO}_{2}$ increasing $\mathrm{H}_{2} \mathrm{O}_{2}$ formation and leading to reductions in $\mathrm{OH}$ in the tropics and increases at $\mathrm{NH}$ mid-latitudes (Figs. 2a and b).

\subsection{Run $3\left(2100 \mathrm{NO}_{\mathrm{x}}\right.$ fossil fuel)}

The tropospheric ozone burden increase was quite large (Table 1), constituting around $41 \%$ of the total increase in the best estimate of 2100 ( 2100 all changes run). Large increases in zonal mean ozone of $5-15 \mathrm{ppb}$ in the SH and 10 $30 \mathrm{ppb}$ in the $\mathrm{NH}$ occurred over wide regions (Figs. 1c and d). All models in Ox_Comp produced largest absolute ozone increases in the upper troposphere, where photochemistry occurred more quickly, despite the fact that $\mathrm{NO}_{\mathrm{x}}$ increases were larger on lower levels. The exact location of the ozone peak appeared to be sensitive to the transport scheme employed. Largest relative changes, however, did occur on lower levels in our runs. For the $2100 \mathrm{NO}_{\mathrm{x}}$ run, increases in $\mathrm{OH}$ of $5-15 \times 10^{5}$ molecules $/ \mathrm{cm}^{3}$ i.e. $20-60 \%$ occurred over wide regions (Figs. 2c and d) but mainly in the tropics. However, $\mathrm{OH}$ was lowered in $\mathrm{NH}$ summer in the upper troposphere at high latitudes. Usually, increased $\mathrm{NO}_{\mathrm{x}}$ is associated with higher $\mathrm{OH}$ via $\mathrm{HO}_{2}+\mathrm{NO} \rightarrow \mathrm{OH}+\mathrm{NO}_{2}$ (reaction 1). A decrease in $\mathrm{OH}$ is more consistent with $\mathrm{NO}_{\mathrm{x}}$ destroying $\mathrm{OH}$ via $\mathrm{OH}+\mathrm{NO}_{2}+\mathrm{M} \rightarrow \mathrm{HNO}_{3}+\mathrm{M}$ (reaction 2). To test this we examined $\mathrm{HNO}_{3}$ but results were inconclusive - it increased by relatively large ( $>1 \mathrm{ppb}$ ) values over much of the $\mathrm{NH}$. A possible explanation for the lowered $\mathrm{OH}$ feature is that increasing ozone with altitude would favor a shift in the partitioning of $\mathrm{HO}_{2}$ into $\mathrm{OH}$ and $\mathrm{NO}$ into $\mathrm{NO}_{2}$. This would favor reaction 2 over reaction 1 . Unfortunately the $\mathrm{NO} / \mathrm{NO}_{2}$ and $\mathrm{OH} / \mathrm{HO}_{2}$ diagnostics were not available for the runs discussed here, but the result has been illustrated by other modeling studies e.g. Hauglustaine et al. (1998) calculated a decrease by a factor five in $\mathrm{HO}_{2} / \mathrm{OH}$ in $\mathrm{NH}$ summer from the ground up to $12 \mathrm{~km}$. Removal of $\mathrm{NO}_{\mathrm{x}}$ by conversion into $\mathrm{HNO}_{3}$ followed by washout (reaction 1) is generally faster in the lower troposphere, which would appear to be inconsistent with the phenomenon occurring in the upper levels. Results suggest that the combined effect of the aforementioned altitude-dependant $\mathrm{HO}_{\mathrm{x}}$ and $\mathrm{NO}_{\mathrm{x}}$ partitioning responses more than compensate the washout effect. Grewe et al. (2001a) concluded that there may exist shortcomings in our chemistry in the upper troposphere, as typically seen in models (Jaegle et al., 1999) perhaps related to the use of Jet Propulsion Laboratory (JPL) 1997 reaction rates, as noted in Shindell et al. (2001). More work is required to explore this theme further.

For the other chemical tracers, $\mathrm{NO}_{\mathrm{x}}$ increased over landmasses mainly in the tropics (500-1500 pptv) and decreased over NH landmasses (300-500 pptv), consistent with the emissions scenario. Largest increases occurred on the lower levels, although there was a secondary peak in the upper troposphere in mid-latitudes. This result, we believe, is sensitive to the model transport scheme. $\mathrm{H}_{2} \mathrm{O}_{2}$ cor-
Table 4. Regional $\mathrm{OH}$ in the control run $\left(10^{5} \mathrm{molec} / \mathrm{cm}^{3}\right)$

\begin{tabular}{ll}
\hline Region & $\mathrm{OH}$ \\
\hline below 800 hPa 90 S-30 S & 3.6 \\
below 800 hPa 30 S-0 & 11.1 \\
below 800 hPa 0-30 N & 15.9 \\
below 800 hPa 30 N-90 N & 11.4 \\
$800-500 \mathrm{hPa} 90 \mathrm{~S}-30 \mathrm{~S}$ & 3.9 \\
$800-500 \mathrm{hPa} 30 \mathrm{~S}-0$ & 9.8 \\
$800-500 \mathrm{hPa} 0-30 \mathrm{~N}$ & 15.2 \\
$800-500 \mathrm{hPa} 30 \mathrm{~N}-90 \mathrm{~N}$ & 11.0 \\
$500-300 \mathrm{hPa} 90 \mathrm{~S}-30 \mathrm{~S}$ & 3.9 \\
$500-300 \mathrm{hPa} 30 \mathrm{~S}-0$ & 11.2 \\
$500-300 \mathrm{hPa} 0-30 \mathrm{~N}$ & 15.0 \\
$500-300 \mathrm{hPa} 30 \mathrm{~N}-90 \mathrm{~N}$ & 8.7 \\
\hline
\end{tabular}

respondingly decreased (by $100-500$ pptv) where $\mathrm{NO}_{\mathrm{x}}$ increased. A significant source of $\mathrm{H}_{2} \mathrm{O}_{2}$ is the self-reaction of $\mathrm{HO}_{2}$. $\mathrm{NO}_{\mathrm{x}}$ increases tended to shift $\mathrm{HO}_{2}$ into $\mathrm{OH}$ (the $\mathrm{NO}_{\mathrm{x}}$ "see-saw" effect), consistent with the $\mathrm{H}_{2} \mathrm{O}_{2}$ decrease. $\mathrm{CH}_{3} \mathrm{OOH}$ also decreased where $\mathrm{NO}_{\mathrm{x}}$ increased, by 50-100 pptv. Again, this was because its main source involved $\mathrm{HO}_{2},\left(\mathrm{CH}_{3} \mathrm{O}_{2}+\mathrm{HO}_{2} \rightarrow \mathrm{CH}_{3} \mathrm{OOH}\right)$. HCHO increased by $200-400$ pptv, mainly in the tropics on the lower levels. The increase tended to follow the landmasses i.e. occurred where $\mathrm{NO}_{\mathrm{x}}$ was directly increased and was associated with enhanced $\mathrm{NO}_{\mathrm{x}}$-catalysed conversion of methane into $\mathrm{HCHO}$ in the model. $\mathrm{HO}_{2} \mathrm{NO}_{2}$ increased mainly in the upper troposphere, rather than on the lower levels, where $\mathrm{NO}_{\mathrm{x}}$ increases were largest. This molecule was sensitive to temperature changes and readily underwent thermal decomposition. Results suggested that on the warmer, lower levels, the molecule is accordingly less sensitive to increases in $\mathrm{NO}_{\mathrm{x}} \cdot \mathrm{HNO}_{3}$ increased mainly over tropical landmasses, consistent with the emissions scenario. Interestingly, at the surface in $\mathrm{NH}$ midlatitudes, despite $\mathrm{NO}_{\mathrm{x}}$ decreases (due to lowered emissions), $\mathrm{HNO}_{3}$ levels still increased (by several ppb). The $\mathrm{HNO}_{3}$ lifetime was sufficiently long to enable travel over synoptic scales hence the $\mathrm{NH}$ mid-latitudes were influenced by the increased photochemical production occurring in the tropics.

\subsection{Run $4\left(2100 \mathrm{CH}_{4}\right)$}

In this run the tropospheric ozone burden increases (Table 1) were comparable to the 2100 industrial $\mathrm{NO}_{\mathrm{x}}$ run. Zonal mean ozone increased most in the NH upper troposphere in July (Fig. 1f). Zonal mean OH decreased in most regions. However, it actually increased in the upper troposphere during summer, where ozone increases peaked (Fig. 2f). It is wellknown that increased ozone may lead to increased $\mathrm{OH}$ via $\mathrm{O}^{1} \mathrm{D}+\mathrm{H}_{2} \mathrm{O}$. Interestingly, $\mathrm{HO}_{2} \mathrm{NO}_{2}$ (which readily underwent thermal decomposition) increased by $100 \mathrm{pptv}$ in the region of interest. Its only source in the model was via 
Table 5. Chemical process budget in July showing a selection of tracers for run 1 (control), run 6 (2100 ocean) and run 10 (all 2100 changes). Values in brackets represent the $95 \%$ confidence interval for the control run. "Normalized" denotes values divided by the global mean species concentration in pptv. Wet deposition refers to large-scale (non-convective) rainout and washout

\begin{tabular}{llllll}
\hline Units & Species & Process & Control & 2100 ocean & All 2100 \\
\hline $10^{3} \mathrm{~kg} / \mathrm{s}$ & $\mathrm{O}_{3}$ & Dry deposition & $-38.3(0.6)$ & -36.8 & -59.9 \\
$10^{3} \mathrm{~kg} / \mathrm{s}$ & $\mathrm{O}_{3}$ & Chemistry & $15.4(0.7)$ & 10.1 & 41.3 \\
$10^{0} \mathrm{~kg} / \mathrm{s}$ & $\mathrm{NO}_{\mathbf{x}}$ & Dry deposition & $-142(3.7)$ & -137 & -358 \\
$10^{0} \mathrm{~kg} / \mathrm{s}$ & $\mathrm{NO}_{\mathrm{x}}$ & Chemistry & $-1,199(7.3)$ & $-1,270$ & $-3,417$ \\
$10^{0} \mathrm{~kg} / \mathrm{s}$ & $\mathrm{HNO}_{3}$ & Moist convection & $-1,104(156.3)$ & $-1,319$ & $-3,245$ \\
$10^{0} \mathrm{~kg} / \mathrm{s}^{*} \mathrm{pptv}$ & $\mathrm{HNO}_{3}$ & Moist convection & -0.683 & -0.801 & -1.290 \\
& & Normalized & & & \\
$10^{0} \mathrm{~kg} / \mathrm{s}$ & $\mathrm{HNO}_{3}$ & Dry deposition & $-2,229(67.9)$ & $-2,289$ & $-5,667$ \\
$10^{0} \mathrm{Kg} / \mathrm{s}$ & $\mathrm{HNO}_{3}$ & Wet deposition & $-798(57.2)$ & -867 & $-2,515$ \\
$10^{0} \mathrm{~kg} / \mathrm{s} * \mathrm{pptv}$ & $\mathrm{HNO}_{3}$ & Wet deposition & -0.494 & -0.527 & -1.00 \\
& & Normalized & & & \\
$10^{0} \mathrm{~kg} / \mathrm{s}$ & $\mathrm{HNO}_{3}$ & Chemistry & $5,372(33.1)$ & 5,689 & 15,279 \\
$10^{0} \mathrm{~kg} / \mathrm{s}$ & $\mathrm{H}_{2} \mathrm{O}_{2}$ & Moist convection & $-5,784(157.8)$ & $-6,233$ & $-6,411$ \\
\hline
\end{tabular}

$\left(\mathrm{HO}_{2}+\mathrm{NO}_{2}+\mathrm{M}\right)$; since temperature increased slightly, and since $\mathrm{HO}_{2}$ decreased, this increase could only have arisen from an increase in $\mathrm{NO}_{2}$. For the remaining chemical tracers, there occurred a large increase (several ppbv) of $\mathrm{H}_{2} \mathrm{O}_{2}$, mainly in the tropics. This change was the largest $(0.5-$ $1.0 \mathrm{ppbv}$ ) of all runs (except for the all changes run) - slightly larger than that of the 2100 ocean run and was associated with enhanced $\mathrm{HO}_{\mathrm{x}}$ from methane oxidation. There was also a large (300-600 pptv) increase in $\mathrm{HCHO}$, especially on the lower levels in the tropics. Again, this increase was larger than any other run $\mathrm{CH}_{4}$ increases, together with the increased $\mathrm{NO}_{\mathrm{x}}$ run, contributed by far the bulk of the $\mathrm{HCHO}$ production).

\subsection{Run 5 (increased CO for NMHC proxy)}

In this run the tropospheric ozone burden increase was small (Table 1), similar to the 2100 industrial CO run. As already stated for that run, this demonstrated that ozone production was more often limited by $\mathrm{NO}_{\mathrm{x}}$, rather than VOC or $\mathrm{CO}$ availability.

\subsection{Run 6 (2100 ocean), chemical response}

Table 5 compares chemical processes for the control, the 2100 ocean run and the run with all changes. Table 6 is as for Table 5 but shows physical processes. The tropospheric ozone burden increased by $2.2 \%$ in January and decreased by $1.4 \%$ in July (Table 1). Other works have reported larger decreases on changing temperature and relative humidity. Johnson et al. (1999) found a 10\% decrease in ozone in July under 2075 conditions. Brasseur et al. (1998) reported a $16.7 \%$ decrease in ozone in 2050 due to climate changes. Lower ozone was associated with the enhanced $\operatorname{sink} \mathrm{O}^{1} \mathrm{D}+\mathrm{H}_{2} \mathrm{O}$ and higher
$\mathrm{OH}$ hence lower $\mathrm{NO}_{\mathrm{x}}$. We do in fact see a large reduction in the net chemical production of ozone (Table 5), though this is largely compensated for by reduced dry deposition and altered circulation.

Our zonal mean ozone (Figs. 1g and $\mathrm{h}$ ) revealed moderate (1-5 ppbv) decreases on lower levels in the summer hemisphere, associated with enhanced water vapor. On upper levels there featured moderate increases $(5-10 \mathrm{ppb})$ associated with increased $\mathrm{NO}_{\mathrm{x}}$ from lightning. Other studies have incorporated fixed lightning, hence overlooked this potential source of ozone, which accounted for some (but probably not all) of our discrepancy with other studies. Grewe et al. (2001b) compared 1990 and 2015 and found that a decrease of precipitation in the tropics led to slower washout hence increased $\mathrm{NO}_{\mathrm{x}}$ of the order $10 \%$ in their model. They also found that cloudwater changes could impact $\mathrm{HNO}_{3}$ washout, hence affect $\mathrm{NO}_{\mathrm{x}}$. In our runs, precipitation also decreased, mainly over the Indian subcontinent (see Sect. 4.6.1) but we found little correlation between cloudwater and $\mathrm{NO}_{\mathrm{x}}$ changes. There were however some similarities in the ozone and cloud responses (see Sect. 4.6.1). The $\mathrm{O}^{1} \mathrm{D}+\mathrm{H}_{2} \mathrm{O}$ sink may be affected by changes in clouds which impact $\mathrm{O}^{1} \mathrm{D}$ via scattering. Future work should examine this further. Finally, Table 5 revealed a $4 \%$ global decrease in dry deposition (an important sink) of ozone for the 2100 ocean run compared with the control. This arose chiefly due to reductions in seaice (some regions, e.g. Hudson Bay, McMurdo Bay suffered up to $50 \%$ loss). Other studies have incorporated fixed seaice hence have overlooked this potential "source" of ozone.

Our global $\mathrm{OH}$ change (Table 1) compared reasonably well with other studies - Brasseur et al. (1998) reported a $7 \%$ annual increase whereas Johnson et al. (1999) reported a $14 \%$ (July) increase in $\mathrm{OH}$ associated with temperature and 
Table 5. Continued

\begin{tabular}{|c|c|c|c|c|c|}
\hline Units & Species & Process & Control & 2100 ocean & All 2100 \\
\hline $10^{0} \mathrm{~kg} / \mathrm{s}^{*} \mathrm{pptv}$ & $\mathrm{H}_{2} \mathrm{O}_{2}$ & $\begin{array}{l}\text { Moist convection } \\
\text { Normalized }\end{array}$ & -5.43 & -4.81 & -3.48 \\
\hline $10^{0} \mathrm{~kg} / \mathrm{s}$ & $\mathrm{H}_{2} \mathrm{O}_{2}$ & Dry deposition & $-2,965(89.0)$ & $-3,421$ & $-3,953$ \\
\hline $10^{0} \mathrm{~kg} / \mathrm{s}$ & $\mathrm{H}_{2} \mathrm{O}_{2}$ & Wet deposition & $-1,073(36.0)$ & $-1,431$ & $-1,636$ \\
\hline $10^{0} \mathrm{~kg} / \mathrm{s}^{*} \mathrm{pptv}$ & $\mathrm{H}_{2} \mathrm{O}_{2}$ & $\begin{array}{l}\text { Wet deposition } \\
\text { Normalized }\end{array}$ & -1.007 & -1.105 & -0.889 \\
\hline $10^{0} \mathrm{~kg} / \mathrm{s}$ & $\mathrm{H}_{2} \mathrm{O}_{2}$ & Chemistry & $11,811(273.7)$ & 13,161 & 14,736 \\
\hline $10^{0} \mathrm{~kg} / \mathrm{s}$ & $\mathrm{CH}_{3} \mathrm{OOH}$ & Dry deposition & $-771.0(9.2)$ & -853 & $-1,622.4$ \\
\hline $10^{0} \mathrm{~kg} / \mathrm{s}$ & $\mathrm{CH}_{3} \mathrm{OOH}$ & Chemistry & $791.0(41.0)$ & 899 & $1,771.9$ \\
\hline $10^{-1} \mathrm{~kg} / \mathrm{s}$ & $\mathrm{HCHO}$ & Dry deposition & $-4,633(93.2)$ & $-4,924$ & $-13,288$ \\
\hline $10^{-1} \mathrm{~kg} / \mathrm{s}$ & $\mathrm{HCHO}$ & Wet deposition & $-404.1(54.2)$ & -498 & $-1,428.9$ \\
\hline $10^{-1} \mathrm{~kg} / \mathrm{s} * \mathrm{pptv}$ & $\mathrm{HCHO}$ & $\begin{array}{l}\text { Wet deposition } \\
\text { Normalized }\end{array}$ & -2.659 & -2.912 & -2.934 \\
\hline $10^{-1} \mathrm{~kg} / \mathrm{s}$ & $\mathrm{HCHO}$ & Moist convection & $112.3(102.7)$ & 84.7 & 727.5 \\
\hline $10^{-1} \mathrm{~kg} / \mathrm{s} * \mathrm{pptv}$ & $\mathrm{HCHO}$ & $\begin{array}{l}\text { Moist convection } \\
\text { Normalized }\end{array}$ & 0.747 & 0.496 & 1.493 \\
\hline $10^{-1} \mathrm{~kg} / \mathrm{s}$ & $\mathrm{HCHO}$ & Chemistry & $6,046(168.3)$ & 6,527 & 17,825 \\
\hline $10^{0} \mathrm{~kg} / \mathrm{s}$ & $\mathrm{HO}_{2} \mathrm{NO}_{2}$ & Chemistry & $-3.8(4.6)$ & -5.3 & +12.3 \\
\hline $10^{2} \mathrm{~kg} / \mathrm{s}$ & $\mathrm{CO}$ & Chemistry & $-342.5(7.4)$ & -332 & -414.0 \\
\hline
\end{tabular}

Table 6. Physical parameters in the model in January for the control run, changed ocean run and all 2100 changes run. All values are global mean. Values in brackets represent the $95 \%$ confidence interval for the control run

\begin{tabular}{lccc}
\hline & Run 1 (control) & Run 6 (2100 ocean) & Run 10 (All 2100) \\
\hline Surface Temperature $\left({ }^{\circ} \mathrm{C}\right)$ & $11.87(0.15)$ & 15.11 & 15.67 \\
Supersaturated cloud $(\%)$ & $42.78(0.54)$ & 43.61 & 42.87 \\
Convective cloud $(\%)$ & $9.99(0.26)$ & 8.88 & 9.07 \\
Precipitation (mm/day) & $3.06(0.05)$ & 2.97 & 3.18 \\
Evaporation (mm/day) & $3.07(0.07)$ & 2.98 & 3.19 \\
Water column (mm) & $21.26(0.13)$ & 27.25 & 27.55 \\
Ocean ice $(\%)($ fixed) & $3.73(0.00)$ & 2.64 & 2.64 \\
Snow cover $(\%)$ & $14.72(0.30)$ & 12.64 & 12.17 \\
d(T)/d(latitude) & $-3.15(1.53)$ & -2.90 & -2.98 \\
Tropospheric static stability & $4.77(0.03)$ & 4.91 & 4.88 \\
\hline
\end{tabular}

humidity increases under doubled $\mathrm{CO}_{2}$ conditions. More recently, Johnson et al. (2001) report $\mathrm{OH}$ changes of -4 to $+19 \%$ depending upon location and season. Zonal mean $\mathrm{OH}$ (Figs. $2 \mathrm{~g}$ and $\mathrm{h}$ ) increased by $2-7 \times 10^{5}$ molecules $/ \mathrm{cm}^{3}$ i.e. $10-35 \%$ compared with the control run, mainly in the tropical upper troposphere and centered at about $20 \mathrm{~N}$ in January moving to $20 \mathrm{~S}$ in July, associated with the seasonal shift of the inter-tropical convergence zone. The high altitude of the peak (despite higher increases in $\mathrm{H}_{2} \mathrm{O}$ at lower levels, not shown) reflected uv availability.

Regarding other chemical tracers in the model, $\mathrm{H}_{2} \mathrm{O}_{2}$ increased by $1-2 \mathrm{ppbv}$, and $\mathrm{CH}_{3} \mathrm{OOH}$ by $50-150$ pptv, both mainly in the tropics, associated with water vapor (hence
$\mathrm{HO}_{\mathrm{x}}$ ) increases, and similar to the responses for the increased methane run. Table 5 shows faster removal of the soluble gases due to wet deposition and convection for the 2100 ocean run. To isolate the cloud effect we also show values normalized by concentration. Results implied a general increase in both wet deposition and moist convection of 5-10\% due to this effect (e.g. wet deposition of $\mathrm{HNO}_{3}$ changed from -0.494 to -0.527$)$. The exception was the moist convective removal of $\mathrm{H}_{2} \mathrm{O}_{2}$, which actually decreased; unlike $\mathrm{HNO}_{3}$, this specie was most abundant in the tropics, where convective clouds decreased slightly (Table 6). 

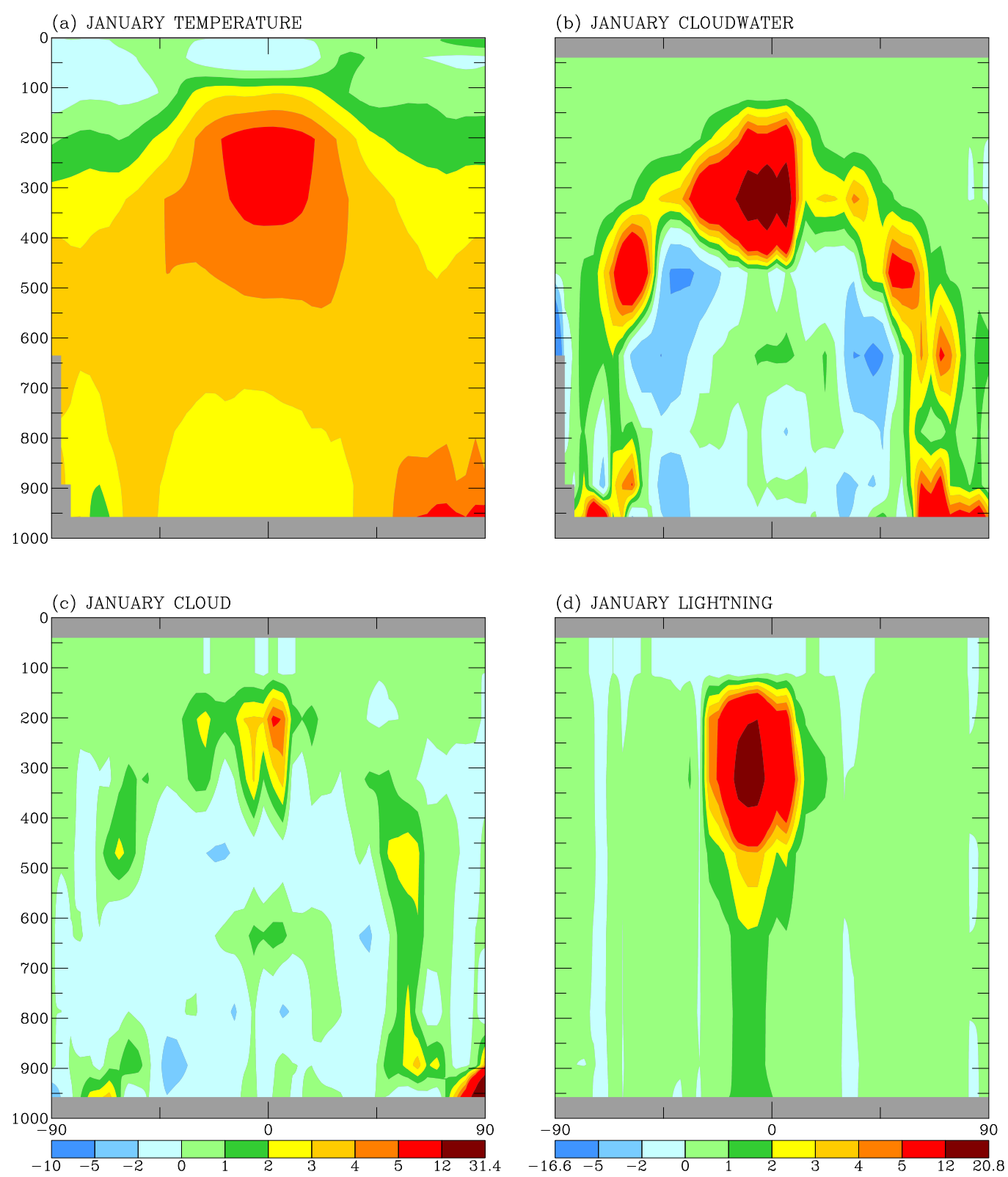

Fig. 3. (2100 ocean - control) in January (a) temperature $(\mathrm{K})$, (b) cloudwater (ppmm), (c) total cloud cover $(\%)$ and $(\mathbf{d}) \mathrm{NO}_{\mathrm{x}}$ from lightning $\left(1 \times 10^{-2} \mathrm{~kg} / \mathrm{s}\right)$.

\subsubsection{Physical response}

Figures 3a-d show changes in zonal mean temperature $\left({ }^{\circ} \mathrm{C}\right)$, cloudwater $\left(1 \times 10^{-6} \mathrm{~kg} / \mathrm{kg}\right)$, total cloud $(\%)$ and production of $\mathrm{NO}_{\mathrm{x}}$ from lightning $\left(1 \times 10^{-2} \mathrm{~kg} \mathrm{NO}_{\mathrm{x}} / \mathrm{s}\right)$ for the 2100 ocean run in January (i.e. during the large NH surface warming). Figures $4 \mathrm{a}-\mathrm{d}$ show a latitude-longitude projection of changes in surface temperature $\left({ }^{\circ} \mathrm{C}\right)$, precipitation (mm/day), total cloud (\%) and lightning (flashes/minute).

Precipitation: This quantity decreased $2.9 \%$ in the global mean (Table 6). The decrease occurred most strongly
$(10-20 \mathrm{~mm} /$ day) over the ocean near the Indian peninsula (Fig. 4b) for this, and other runs with modified oceans, both in winter and summer. Curiously, the model calculated a general increase in the land-sea temperature contrast, which would argue for a stronger Asian monsoon with heavier precipitation. The model sometimes had problems in capturing mesoscale dynamics, especially over peninsulas and islands, due to its rather coarse horizontal resolution, so may not be the best tool to simulate the Monsoon. Many factors influence the Monsoon response - it is beyond the scope of this paper to enter into a discussion of them all. 
3.23

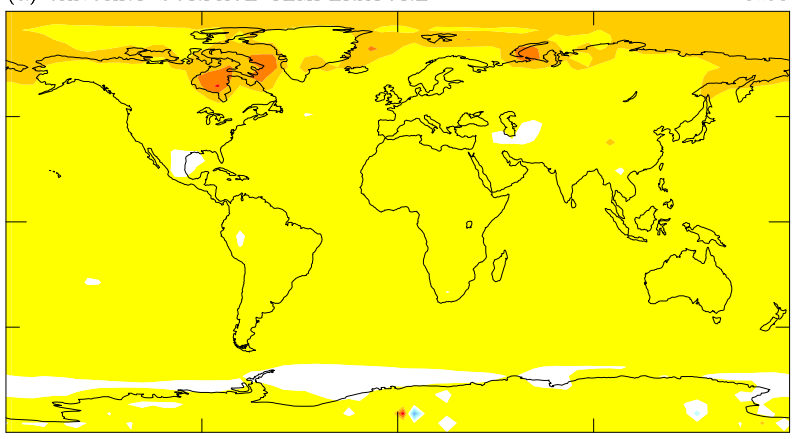

(c) JANUARY CLOUD

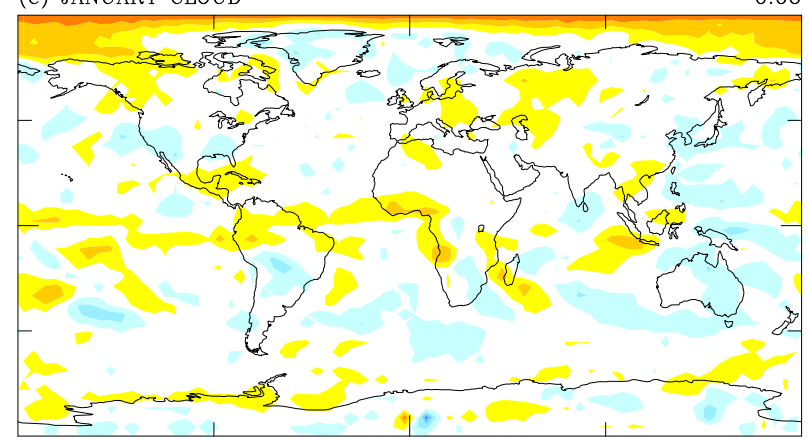

(b) JANUARY PRECIPITATION

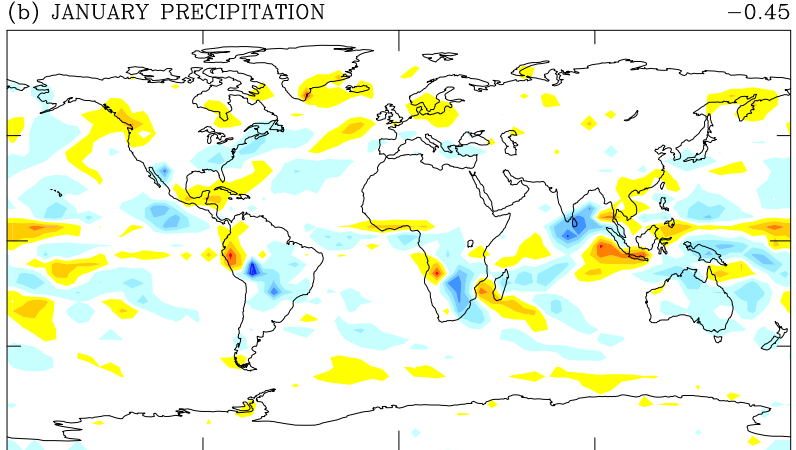

(d) JANUARY LIGHTNING

0.84

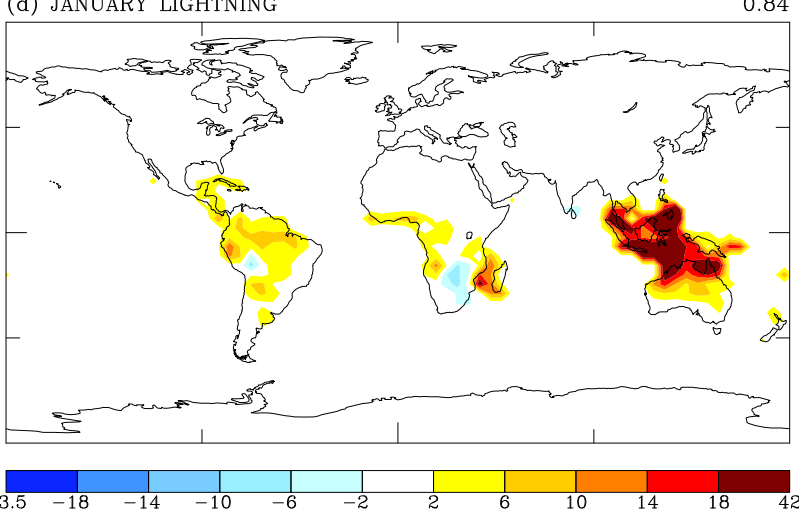

Fig. 4. (2100 ocean - control) in January (a) surface temperature (K), (b) precipitation (mm/day), (c) total cloud in column (\%) and (d) total lightning in column (flashes/minute); precipitation has been multiplied by 5 , cloud by 0.5 , lightning by $5 \times 10^{-4}$.

Temperature (and clouds): The mean surface temperature increased from $11.87^{\circ} \mathrm{C}$ in the control run to $15.12^{\circ} \mathrm{C}$ in the 2100 ocean run (Table 6). Large, wintertime warming (5$10 \mathrm{~K}$ ) extended from 45 to $90^{\circ}$ in both hemispheres (Figs. 3a and 4a). Interestingly, the response in the run with all 2100 changes tended to be higher than the linear sum of the individual runs which suggested some non-linear feedback process in operation. The supersaturated clouds were enhanced mainly in the lower troposphere where they may effectively trap outgoing thermal radiation (increasing the radiative forcing there by $10-20 \mathrm{~W} / \mathrm{m}^{2}$ ) and lead to surface warming. The latitude-longitude plots (Figs. 4a and c) however, showed that although there was some correlation between increased clouds and increased surface temperatures in NH mid-high latitude winter, this was not always the case. For example, Hudson Bay warmed massively, but showed only a small cloud increase. On inspecting the sea-ice change (not shown) it was clear that areas such as this suffered large decreases in albedo due to lowered sea-ice, which decreased by $29.2 \%$ in the global mean (Table 6). Lowered surface albedo tended to increase surface warming directly.

Lightning (and clouds): Figs. $3 \mathrm{~d}$ and $4 \mathrm{~d}$ revealed largest lightning increases in the tropical upper troposphere, espe- cially over Micronesia and the Amazon Basin. $\mathrm{NO}_{\mathrm{x}}$ from lightning (Table 5) increased globally from $4.89 \mathrm{TgN} / \mathrm{year}$ in the control run to $6.86 \mathrm{TgN} / \mathrm{year}$ for the 2100 ocean run. Given this result, it was at first puzzling that total convective cloud cover should decrease to such an extent (Table 6). The explanation lay in increased deep convective frequencies. Decreased shallow convective cover and frequency led to an overall decrease in total convective cloud cover. Decreased convective cloud cover over wider scales was associated with weakened Hadley overturning in the tropics and occurred despite water vapor increases. Supersaturated cloud cover (and water vapor) tended however to increase (except for run 9, i.e. all changes except $\mathrm{NO}_{\mathrm{x}}$ fossil fuel). It appeared therefore to be more sensitive to water vapor increases and less sensitive to the weakening in vertical overturning. Supersaturated clouds are more important regulators of climate (Del Genio et al., 1996; Poetzsch-Heffter et al., 1995) due to greater coverage and longer lifetimes compared with convective clouds. In ppbv NOx the lightning increases corresponded to $+5.8 \%(202 \mathrm{hPa}),+3.2 \%(322 \mathrm{hPa})$ and $+1.5 \%$ (470 hPa). 


\subsection{Run 7 (2100 aircraft)}

Interestingly, the total tropospheric ozone burden (Table 1) did not change appreciably. Increases of $10-20 \%$ occurred in the NH but these were offset by smaller decreases which occurred throughout the SH (not shown). The SH signal was only of low significance (1-2 sigma). Global mean $\mathrm{OH}$ increased by $1.8 \%$ in January and $2.9 \%$ in July. Zonal mean $\mathrm{OH}$ increased everywhere except in the upper troposphere at high latitudes similar to the 2100 fossil fuel emissions as already discussed in Sect. 4.3.

Regarding the other chemical tracers, $\mathrm{NO}_{\mathrm{x}}$ increased mainly in the $\mathrm{NH}$ mid-latitude upper troposphere by 50 100 pptv in January and 100-200 pptv in July. There was a smaller $(\sim 50 \mathrm{pptv})$ peak at the surface immediately below. $\mathrm{HO}_{2} \mathrm{NO}_{2}$ also increased in the $\mathrm{NH}$ upper troposphere, by $25-50$ pptv, comparable to the run with 2100 industrial $\mathrm{NO}_{\mathrm{x}}$ (run 3). $\mathrm{HNO}_{3}$ increased by $100-200$ pptv throughout the NH mid-latitude troposphere. Remaining tracers showed only small responses.

\subsection{Run $8\left(21001.1 * \mathrm{CH}_{4}\right)$}

This, together with the "all changes except $\mathrm{NO}_{\mathrm{x}}$ " run were both stand-alone runs, whereas the other runs all combined to produce run 10 (the all 2100 changes run). Run 8 was performed by Ox_Comp to investigate the sensitivity of present day $\mathrm{OH}$ to a prescribed (10\%) increase in methane. The tropospheric ozone burden (Table 1) did not change appreciably. Global mean $\mathrm{OH}$ decreased by $3.6 \%$ in January and $2.2 \%$ in July (annual mean, $2.9 \%$ decrease). This compared reasonably well with other Ox_Comp models, who reported (annual) decreases in the range 2.9-3.5\% (IPCC, 2001).

\subsection{Run 9 (All 2100 changes except $\mathrm{NO}_{\mathrm{x}}$ )}

The rationale here was to investigate the response of $\mathrm{OH}$ without the positive influence of a future $\mathrm{NO}_{\mathrm{x}}$ increase. Global mean $\mathrm{OH}$ decreased by $16.1 \%$ in January and $16.2 \%$ in July (Table 1). This result differed from the other four Ox_Comp models who performed this scenario. They reported a $41 \%, 39 \%, 37 \%$ and $43 \%$ decrease (mean $=-40 \%$ ). Some of the discrepancy arose because, unlike the other models, we changed the SSTs. This counteracted the decrease in $\mathrm{OH}$ (from increased VOCs) by increasing the water vapor.

\subsection{Run 10 (All 2100 changes)}

In this run the tropospheric ozone burden increased by $42.4 \%$ in January and $41.1 \%$ in July (Table 1), corresponding to a mean increase of 15.8 DU throughout the troposphere. This compared very well with the Ox_Comp results which were in the range 14.7 to $16.5 \mathrm{DU}$ (TAR, Table 4.11; using $1 \mathrm{DU}=10.94 \mathrm{Tg}$ ). Figures $1 \mathrm{k}$ and 1 , which show the zonal mean absolute change in ozone, revealed large (40-50 ppbv) surface increases in NH mid-latitudes and even larger (40$80 \mathrm{ppbv}$ ) increases in the upper troposphere in tropical to mid-latitude regions. Compared with run 9 (all changes except $\mathrm{NO}_{\mathrm{x}}$ ), approximately half this ozone increase was attributable to increased $\mathrm{NO}_{\mathrm{x}}$ from fossil fuel. The GISS model produced a rather large July maximum at around $300 \mathrm{mb}$ in the NH extra-tropics comparable to the UCI model and MOZART2 (see TAR, Fig. 4.12) but calculated smaller increases in other regions. Differing zonal mean behavior between Ox_Comp models was attributed by TAR mainly to differences in the model transport schemes. Our model differed in that we changed the SSTs (hence increased the water vapour), and did not explicitly include NMHCs. These two factors suggest decreased ozone in our model. On the other hand, we included online clouds, calculated an increase in $\mathrm{NO}_{\mathrm{x}}$ due to lightning, and decreased ozone dry deposition via decreased ocean ice. These factors suggest increased ozone. The overall result has placed us well within the range quoted by the other Ox_Comp models.

Our global mean $\mathrm{OH}$ change (Table 1) was quite different from the other Ox_Comp models, who reported an annual mean decrease in the range 6 to 25\% (mean 16\%). However, as already mentioned, we changed the SSTs, which led to increased $\mathrm{OH}$ via increased water vapor. There have been several recent modeling studies of future climate change who also changed the SSTs, and who reported increased OH. Our results were rather higher than those studies. For example, Brasseur et al. (1998) reported a 2.2\% annual increase in $\mathrm{OH}$ due to the combined effect of anthropogenic emissions and changes in temperature and relative humidity. However, those authors employed $\mathrm{NO}_{\mathrm{x}}$ increases only up to 2075, and did not use the highest emissions scenario. Johnson et al. (1999) similarly reported -2 to $+4 \%$ change depending on season but they employed $\mathrm{NO}_{\mathrm{x}}$ changes only until 2050 and also did not use the highest emissions scenario. The percentage changes in industrial $\mathrm{NO}_{\mathrm{x}}$ were: present work $=(79 \%)$; Brasseur et al. (1998) $=55 \%$; Johnson et al. (1999) $=73 \%$ - Also, our model produced more $\mathrm{NO}_{\mathrm{x}}$ due to lightning. Finally, there featured increased $\mathrm{OH}$ in $\mathrm{NH}$ summer in our model which we believe was related to increased ozone in this region (see Sect. 4.4). Zonal mean OH (Figs. 2k and l) nicely revealed the opposing influences of the various individual runs. For example. it increased in the tropics at the ground (due to the 2100 industrial $\mathrm{NO}_{\mathrm{x}}$ run ; Figs. $2 \mathrm{c}$ and d), in the upper troposphere (due to the changed ocean, Figs. $2 \mathrm{~g}$ and $\mathrm{h}$ ) and in the extratropics on the upper levels (due to the ozone effect arising from increasing the methane, already discussed) whereas it decreased in mid to high latitudes in both hemispheres, due to increased industrial $\mathrm{CO}$, methane and NMHCs (e.g. Figs. 2a, b, e, and f).

Regarding the remaining chemical tracers, $\mathrm{NO}_{\mathrm{x}}$ increased by $1-2$ ppbv mainly in the tropics and on the lower levels (consistent with the industrial emissions scenario) but also featured a secondary peak (up to $200 \mathrm{ppt}$ ) in the $\mathrm{NH}$ extra tropics associated with increased lightning and aircraft 

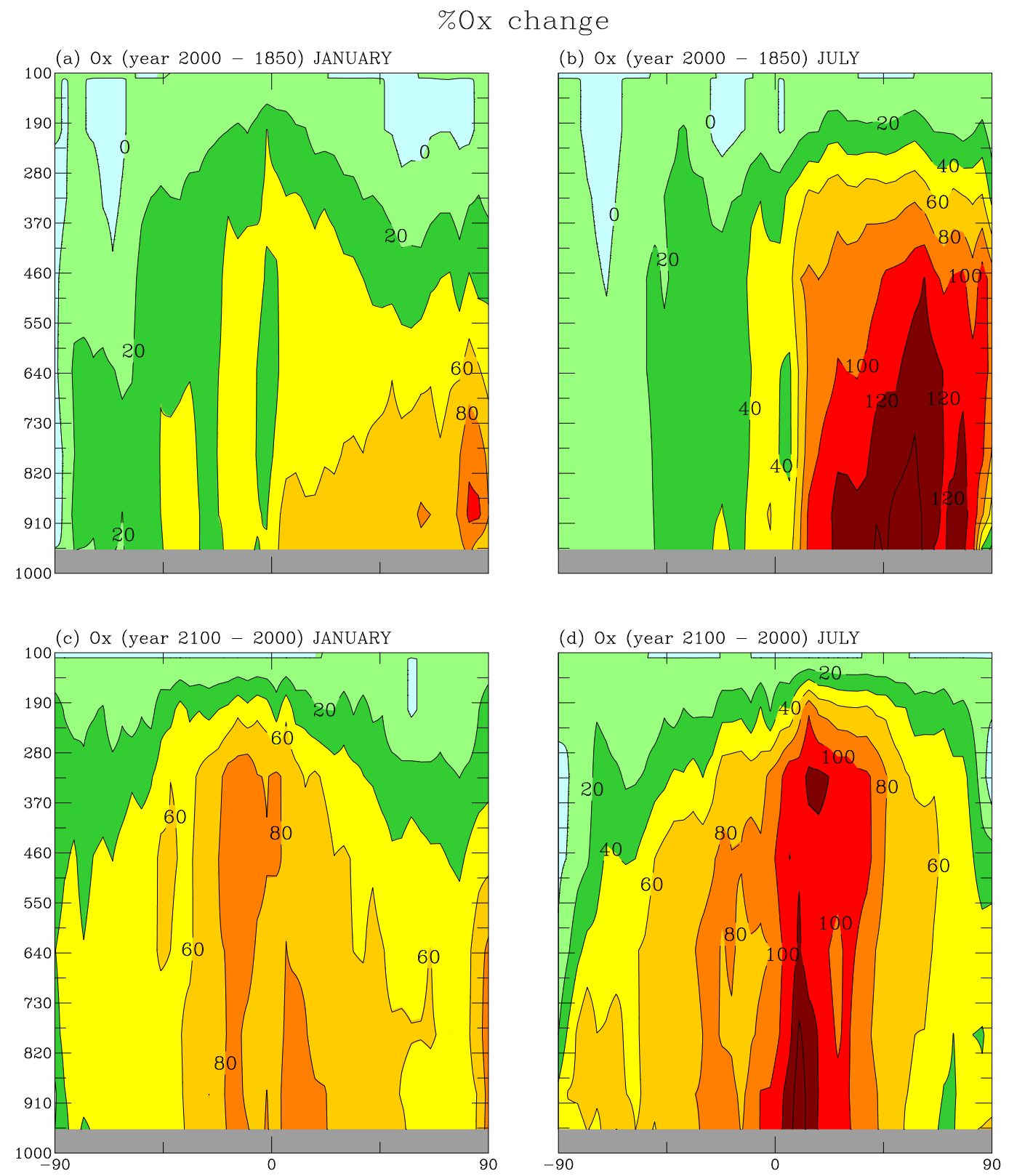

Fig. 5. \%Ozone change in (a) January, (b) July, 1850 to 2000; (c) January, (d) July for the all changes run - control run.

emissions. It decreased by $300-400$ pptv in the NH upper troposphere associated with the anomalous increased $\mathrm{OH}$ from the increased $\mathrm{CH}_{4}$ (see Sect. 4.4 for further details). In the tropics, $\mathrm{H}_{2} \mathrm{O}_{2}$ increased on all levels by $2-3 \mathrm{ppbv}$, as did $\mathrm{CH}_{3} \mathrm{OOH}$ by $500-1000$ pptv; both effects arose mainly from (in order of importance) the changed $\mathrm{CH}_{4}$ and ocean runs. $\mathrm{HO}_{2} \mathrm{NO}_{2}$ increased on the upper levels (but not the lower levels, see Sect. 4.3) by 50-200 pptv, associated with (in order of importance) the $\mathrm{CH}_{4}$, industrial $\mathrm{NO}_{\mathrm{x}}$ and aircraft runs. $\mathrm{HCHO}$ increased by 1-2 ppbv mainly in the tropics on the lower levels, associated mainly with the changed $\mathrm{CH}_{4}$ and industrial $\mathrm{NO}_{\mathrm{x}}$ runs. CO increased by $50-100 \mathrm{ppbv}$, mainly in the tropics and decreased by 20-25 ppbv over Europe and North America (due to decreasing emissions); the tropical increase was associated mainly with (in order of importance) the changed $\mathrm{CH}_{4}$ and $\mathrm{CO}$ industrial runs.

A central question which coupled chemistry-climate models may address is the change in downward fluxes of ozone and $\mathrm{NO}_{\mathrm{x}}$ from the stratosphere to the troposphere. As mentioned in Sect. 2, the model used in the present study has a very limited stratosphere, although future work will include a more realistic stratosphere to enable us to better understand 
Table 7. Changes in $\mathrm{Ox}\left(10^{3} \mathrm{Kg} / \mathrm{s}\right)$ and $\mathrm{NO}_{\mathrm{x}}(\mathrm{Kg} / \mathrm{s})$ over the tropospheric column in July arising from (1) vertical advection and (2) chemistry for the control (run 1), 2100 ocean (run 6) and all 2100 changes (run 10). Data has been averaged over the latitude bands 2-26 N (a region of overall ascent) and 34-42 N (a region of overall descent). Values in brackets represent the $95 \%$ confidence interval for the control run

\begin{tabular}{lcccc}
\hline & Ozone (2-26 N) & Ozone (34-42 N) & $\mathrm{NO}_{\mathrm{x}}(2-26 \mathrm{~N})$ & $\mathrm{NO}_{\mathrm{x}}(34-42 \mathrm{~N})$ \\
\hline $\begin{array}{l}\text { Control (run 1) } \\
\text { advection }\end{array}$ & $-18(3.5)$ & $11(3.7)$ & $-22(1.7)$ & $1(2.4)$ \\
chemistry & $-0.1(0.1)$ & $4.2(0.1)$ & $-147(3.3)$ & $-236(4.9)$ \\
$\begin{array}{l}2100 \text { Ocean (run 8) } \\
\text { advection }\end{array}$ & -19 & 11 & -27 & 1 \\
$\begin{array}{l}\text { chemistry } \\
\text { All 2100 (run 10) }\end{array}$ & -1.4 & 3.9 & -162 & -247 \\
$\begin{array}{l}\text { advection } \\
\text { chemistry }\end{array}$ & -48 & 11 & -137 & 29 \\
\hline
\end{tabular}

the effects of climate on stratospheric-tropospheric exchange (STE). We have nevertheless calculated a first-order estimate of STE processes (Table 7). In our model, $\mathrm{NO}_{\mathrm{x}}$ and ozone were fixed, and proportional to each other in the stratosphere. Table 7 shows $\mathrm{Ox}$ and $\mathrm{NO}_{\mathrm{x}}$ changes in July due to vertical advection and chemistry averaged over the tropospheric column and across latitude band 2-26 N (a region of overall ascent) and 34-42 N (a region of overall descent) for the control run, the 2100 ocean run and the 2100 all changes run. For the 2100 ocean run Ox advective changes were not significant compared with the variability of the control run. The chemistry changes were, however significant for this run and led to a lowering in Ox consistent with the reaction $\mathrm{O}^{1} \mathrm{D}+\mathrm{H}_{2} \mathrm{O}$, as explained previously. The advection diagnostic reflected changes in (a) the large-scale meridional circulation and (b) eddy diffusion rates, a function of concentration difference in adjacent gridboxes for a particular specie. Recall that the meridional circulation, i.e. process (a), tended to weaken for both the 2100 ocean run and the 2100 all changes run. Also, the increase in ozone in the troposphere by 2100 would tend to weaken the downward diffusional flux of ozone, i.e. process (b), from the stratosphere to the troposphere. Both these factors together would tend to decrease the advective term in the region of descent. However, Table 7 implied little change - evidently such processes impacted ozone only to a minor extent in the model. In the region of ascent, a weaker (a) would tend to increase ozone (less transported upwards) whereas a weaker (b) would tend to decrease ozone (weaker downward diffusional flux due to higher ozone in the troposphere). Table 7 implied that process (b) was the more important. For $\mathrm{NO}_{\mathrm{x}}$ the 2100 ocean run chemical loss increased significantly consistent with the faster chemical removal of $\mathrm{NO}_{\mathrm{x}}$ in the damper, warmer atmosphere. For the advective terms, in the region of ascent the same result held for $\mathrm{NO}_{\mathrm{x}}$ as for Ox. In the region of descent, however, the opposite was true i.e. despite a weakening in (a) and (b), the advective term increased for the all 2100 changes run. Here, $\mathrm{NO}_{\mathrm{x}}$ increased to such an extent in the troposphere that the vertical gradient at the tropopause was sometimes actually negative with height (though the stratospheric abundance, which is fixed here, may increase in the real world as nitrous oxide emissions grow). Then, the upward diffusional flux coupled with the slower meridional circulation led to an overall increase in the advective contribution. However, this increase was small in comparison with the increase in the chemical sinks. Naturally it would be interesting to repeat this diagnosis using a model with better vertical resolution, a higher lid and interactive stratospheric chemistry.

\subsubsection{Future/past response of the Hadley/Ferrel cells}

Grenfell et al. (2001) have used the same model to investigate chemistry-climate interaction occurring from the preindustrial (PI) era (1850) to the present (2000). Those authors calculated broadly comparable results to other, similar studies in the literature. However, they noted a strengthening of the meridional circulation from 1850 to 2000, whereas the present work has suggested a weakening from 2000 to 2100. The PI response was attributed to warmer SSTs leading to large increases in (absolute) water vapor in the lower troposphere. Enhanced radiative heating then resulted in decreased dynamical stability in the lower troposphere which strengthened the upward branch of the Hadley cell. But such an effect also occurred in the runs analyzed here, so the situation must be more complex. A possible explanation is the differing ozone and water distributions. An important caveat here is, due to the fixed SSTs in the model these substances could only affect the temperature away from the surface. When considering changes in heating rate it is preferable to examine \% ozone (and water) change rather than the absolute change. Figurs $5 \mathrm{a}$ and $\mathrm{b}$ show the $\%$ ozone change since PI in January and July; Figs. 5c and d show the same quantity but from 2000 to 2100 , for the 2100 all changes run. In July, industrialization (Fig. 5b) led to largest \%ozone increases in the NH lower troposphere at around $55 \mathrm{~N}$. This 

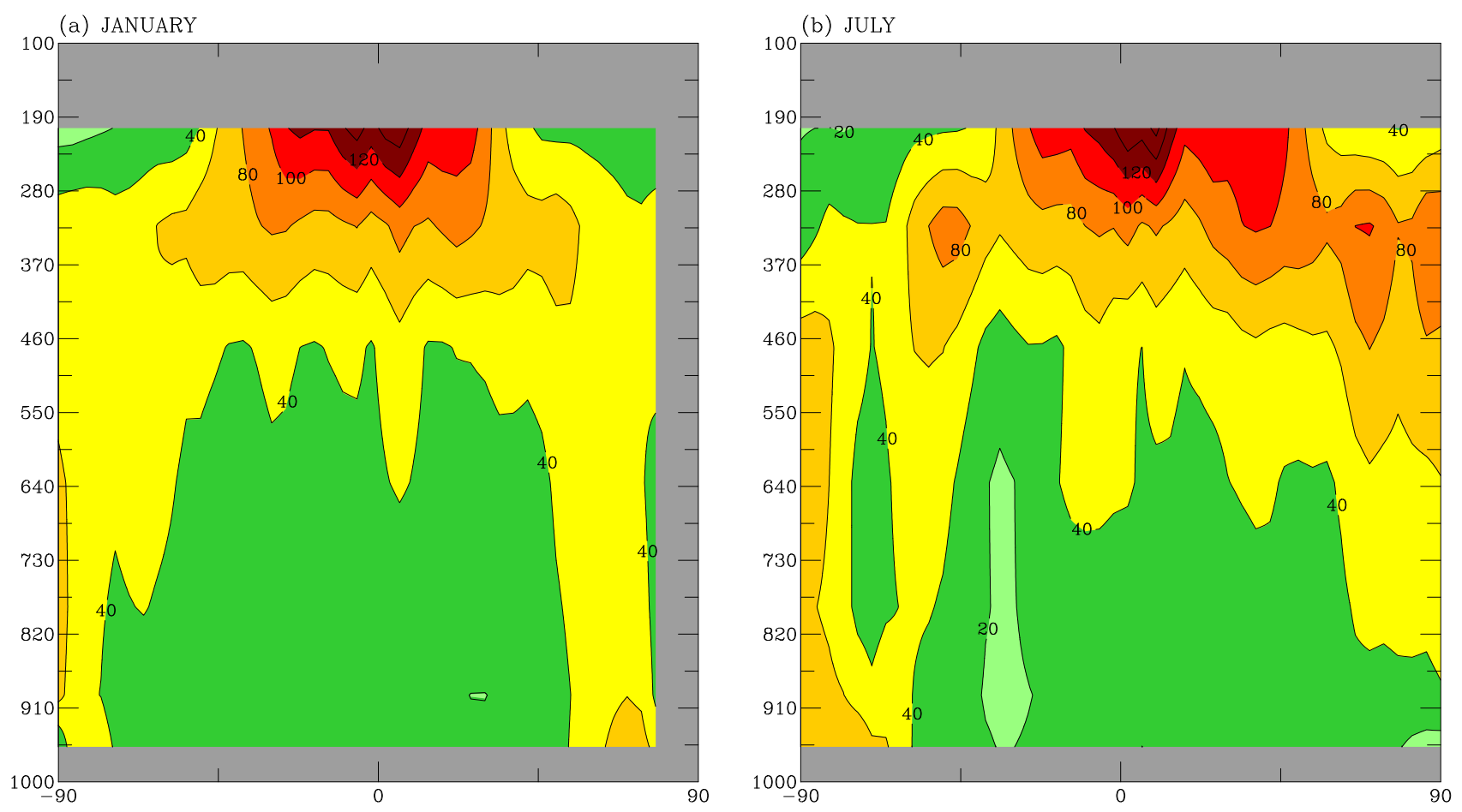

Fig. 6. \%Water change in (a) January, (b) July for the all changes run - control run.

favored heating below the ascending branch of the Ferrel cell hence tended to strengthen the meridional circulation. In July, the all 2100 changes run, with its very different emissions scenario, led to \%ozone increases mainly in tropical regions which peaked at the ground and at $300 \mathrm{mb}$. The lower peak tended to strengthen, whereas the upper peak tended to weaken the upward branch of the Hadley cell. Figures 6a and $\mathrm{b}$ show \%water vapor change for the all 2100 changes run in January and July. The \%peak occurred in the tropical upper troposphere and extended over both Hadley and Ferrel cells. The PI \% water response (not shown), was similar except more confined in latitude (from $5 \mathrm{~N}$ to $5 \mathrm{~S}$ ), which also tended simultaneously to weaken the ascending Hadley branch and strengthen the descending branch. In summary, results suggested that the ozone rather than the water changes were responsible for the differing behavior for the PI, compared with the 2100 runs. The water changes tended to strengthen and weaken alternate branches of the circulation in both sets of runs whereas the ozone changes tended to favour a strengthening in the circulation from 1850 to 2000 and a weakening from 2000 to 2100 . Again, we stress that the impact may be quite different when SSTs are allowed to respond to the chemical changes.

\section{Conclusions and future work}

Our results imply that the major contributors to anthropogenic ozone production over the coming century will be $\mathrm{NO}_{\mathrm{x}}$ fossil fuel and methane increases. The run with all 2100 changes suggested a July increase of $41.1 \%$ for ozone and $11.8 \%$ for $\mathrm{OH}$. The extra ozone occurred mainly in the tropics and extra-tropics where most levels featured an increase of $100-130 \%$. OH was enhanced most (by $20-60 \%$, especially in the tropics) due to $\mathrm{NO}_{\mathrm{x}}$ increases from 2100 fossil fuels and to a lesser extent due to increases in lightning and aircraft emissions. Roughly two-thirds of this increase was offset by decreases arising from increases in methane and to a lesser extent industrial CO and NMHCs. Although global mean $\mathrm{OH}$ decreased in these runs, $\mathrm{OH}$ was consistently increased in the NH upper troposphere in summer. This was possibly related to especially high ozone (see Sect. 4.4 for further details). Changing the ocean from 2000 to 2100 conditions led to generally higher ozone in our model compared with other studies which investigated the effect of temperature and relative humidity changes. A possible explanation for this is, we included $\mathrm{NO}_{\mathrm{x}}$ increases due to lightning changes. To our knowledge, this effect is not accounted for in other studies (except for the recent Johnson et al., 2001 study).

The model has compared well with Ox_Comp results in two regards. Firstly, the response of $\mathrm{OH}$ to a $10 \%$ increase 
in methane yielded a $2.9 \%$ decrease for our model compared with a decrease in the range 2.9 to $3.5 \%$ for the Ox_Comp models. Secondly, our all 2100 changes run produced a 15.8 DU mean increase in the tropospheric ozone burden, compared with 14.7-16.5 DU for the other Ox_Comp models.

Results are obviously sensitive to the emissions scenario. The A2p scenario employed the highest emissions of the four IPCC marker scenarios. Our runs did not include increases in $\mathrm{SO}_{2}$ (hence sulfate aerosol) and $\mathrm{NH}_{3}$ specified by A2p. The magnitude and distribution of future isoprene and other NMHC emissions are generally uncertain and were accounted for indirectly by estimating an equivalent $\mathrm{CO}$ burden increase. Also, the direct radiative impact of increased CO did not feature in our radiative calculations, although this is likely to be small (Ramanathan et al., 1987). Future work should address these uncertainties.

It is interesting to dicuss how our results would change had we analyzed only one year (as in the TAR study). Global mean ozone and $\mathrm{OH}$ did not change greatly from year to year (varying from 401 to $403 \mathrm{Tg}$ and from 5.5 to $5.6 \times 10^{5}$ molecules $/ \mathrm{cm}^{3}$ in January respectively). Rather more internal variability was evident however, on moving to a single level. On the lowermost level (centered at $959 \mathrm{hPa}$ ) January zonal ozone varied year-to-year from 36 to $40 \mathrm{ppbv}$ in the NH (2-sigma NH-mean=2.7 ppbv) and from 20 to $22 \mathrm{ppbv}$ in the $\mathrm{SH}$ (2-sigma SH-mean $=1.7 \mathrm{ppbv})$. For $\mathrm{OH}$ in January, the lowermost level featured 6.45 (2-sigma NHmean $=0.1) \times 10^{5}$ molecules $/ \mathrm{cm}^{3}$. On moving to zonal bands, the variability increased significantly, e.g. at $2^{\circ} \mathrm{N}$, January $\mathrm{OH}$ mean $=11.15$, $(2$-sigma $=0.66) \times 10^{5}$ molecules $/ \mathrm{cm}^{3}$, and at a single location would be commensurately greater. Previous tests with earlier versions of the GISS model without interactive chemistry have suggested that the atmospheric variability increases by up to an order of magnitude when the ocean is allowed to respond.

What impact could our crude stratosphere have on the results? Estimating this is difficult because the Brewer-Dobson (BD) circulation may strengthen or weaken in response to GHG forcing depending on subtle changes in the refractive index and amplitude of planetary waves (PWs). There exist complex feedbacks between wave activity, temperature and ozone loss at high latitudes. A weakened BD circulation, for example (with less PW forcing) would imply less stratospheric-tropospheric exchange hence less downward transport of ozone and $\mathrm{NO}_{\mathrm{x}}$.

Comparing this work with Grenfell et al. (2001), which investigated changes since the pre-industrial (PI) era, has suggested that the meridional circulation in the troposphere may strengthen or weaken depending on the water vapor and ozone responses. An increase in ozone (a heating source) occurring at the bottom of a rising Hadley branch, for example, will tend to strengthen, whereas an ozone increase occurring at the top of the branch will tend to weaken the circulation. The Ox_Comp study showed considerable differences in the peak height, and latitude of the ozone response. The NH PI ozone response (which led to a stronger circulation) calculated by Grenfell et al. (2001) tended to occur poleward of the 2100 response (which led to a weaker circulation) due to the differing emissions scenarios.

Acknowledgement. The authors thank D. Koch for providing the sulfate data, O. Wild and M. Prather for providing the original fastj photolysis code, J. Lerner for providing the 2100 ocean, R. Rudy for useful advice and D. Rind for helpful discussion. We thank N. Savage for referee comments and T. Karl for a short comment. This work was funded under NASA's Atmospheric Chemistry Modeling and Analysis Program, NASA NCC5-328 and EOS NCC 5-270.

\section{References}

Baughcum, S. L., Tritz, T. G., Henderson, S. C., and Pickett, D. C.: Scheduled Civil Aircraft Emission Inventories for 1992: Database development and Analysis, NASA CR-4700, 1996.

Bengtsson, L., Botzet, M., and Esch, M.: Will greenhouse gasinduced warming over the next 50 years lead to higher frequency and greater intensity hurricanes?, Tellus, 48A, 57-73, 1996.

Brasseur, G. P., Kiehl, J. T., Muller, J. F., Schneider, T., Granier, C., Tie, X. X., and Hauglustaine, D.: Past and future changes in global tropospheric ozone and climate: impact on radiative forcing, Geophys. Res. Lett., 25, 3807-3810, 1998.

Collins, W. J., Derwent, R. G., Johnson, C. E., and Stevenson, D. S.: The impact of human activities on the photochemical production and destruction of tropospheric ozone, Quart. J. Roy. Met. Soc., Part A, 126, 566, 1925-1951, 2000.

Del Genio, A. D. and Yao, M. S.: A prognostic cloud water parameterization for global climate models: The GISS scheme, Am. Meteorol. Soc. Monogr., 46, 181-184, 1993.

Del Genio, A. D., Yao, M. S., Kovarl, W., and Lo, K. K. W.: A prognostic cloud water parameterization for global climate models, J. Clim., 9, 2, 270-304, 1996.

Dentener, F. J. and Crutzen, P. J.: Reaction of $\mathrm{N}_{2} \mathrm{O}_{5}$ on tropospheric aerosols: Impact on the global distributions of $\mathrm{NO}_{\mathrm{x}}, \mathrm{O}_{3}$, and $\mathrm{OH}$, J. Geophys. Res., 98, 7149-7163, 1993.

Grenfell, J. L., Shindell, D. T., Koch, D., and Rind, D.: Chemistryclimate interactions in the Goddard Institute general circulation model. 2. New insights into modeling the pre-industrial atmosphere, J. Geophys. Res., 106, 33 435-33 451, 2001.

Grewe, V., Brunner, D., Dameris, M., Grenfell, J. L., Hein, R., Shindell, D., and Staehelin, J.: Origin and variability of upper tropospheric nitrogen oxides and ozone at northern mid-latitudes, Atmos. Environ., Part B, 53, 1-19, 2001a.

Grewe, V. M., Dameris, M., Hein, R., Sausen, R., and Steil, B.: Future changes in the atmospheric composition and the impact of climate change, Tellus, Ser. B, 53, 103-121, $2001 \mathrm{~b}$.

Hauglustaine, D. D., Brasseur, G. P., Walters, P. J., Rasch, J.-F., Muller, L. K., Emmons, and Carroll, M. A.: MOZART, a global chemical transport model for ozone and related chemical tracers 2. Model results and evaluation, J. Geophys. Res., 103, $28291-$ $28335,1998$.

Hansen, J., Russell G., Rind, D., Stone P., Lacis, A., et al.: Efficient three-dimensional global models for climate studies: models I and II, Mon. Weather Rev., 111, 609-662, 1983. 
Hansen, J., Sato, M., Ruedy, R., Lacis, A., Asamoah, K., et al.: Forcings and chaos in interannual to decadal climate change, $\mathrm{J}$. Geophys. Res., 102, 25 679-25 720, 1997.

IPCC (Intergovernmental Panel on Climate Change): Climate change 1995: the science of climate change, edited by J. T. Houghton, Meira Filho, L. G., Callander, B. A., Harris, N., Kattenberg, A., et al., Cambridge University Press, Cambridge UK, 1996.

IPCC (Intergovernmental Panel on Climate Change): Climate Change 2001: the scientific basis, contribution of working group 1 to the third assessment report (TAR) of the intergovernmental panel on climate change, Houghton, J. T., Ding, Y., Griggs, D. J., Noguer, M., van der Linden, P. J., et al. (Eds), Cambridge University Press, UK and New York, NY, USA, 881, 2001.

Jaegle, L., D. Jacob, J., Brune W. H., Faloona, I. C., Tan, D., et al.: Ozone production in the upper troposphere and the influence of aircraft during SONEX: Approach of $\mathrm{NO}(\mathrm{x})$-saturated conditions, Geophys., Res. Lett., 26, 3081-3084, 1999.

Johnson, C. E., Collins, W. J., Stevenson, D. S., and Derwent, R. G.: The relative roles of climate and emissions changes on future oxidant concentrations, J. Geophys. Res., 104, 18 631-18645, 1999.

Johnson, C. E., Stevenson D. S., Collins, W. J., and Derwent R. G.: Role of climate feedback on methane and ozone studied with a coupled Ocean-Atmosphere-Chemistry model, Geophys. Res. Lett., 28, 1723-1726, 2001

Kato, N., and Akimoto, H.: Anthropogenic emissions of $\mathrm{SO}_{2}$ and $\mathrm{NO}_{\mathrm{x}}$ in Asia: Emissions inventories, Atmos. Environ., 26A, 2997-3017, 1992.

Koch, D., Jacob, D., Tegen, I., Rind, D., and Chin, M.: Tropospheric sulfur simulation and sulfate direct radiative forcing in the Goddard Institute for Space Studies general circulation model, J. Geophys. Res., 104, 23 799-23 822, 1999.

Lawrence, M. G., Joeckel, P., and von Kuhlmann R.: What does the global mean $\mathrm{OH}$ concentration tell us? Atmos. Chem. Phys. Disc., 1, 43-75, 2001.

Mickley, L., Murti, P. P., Jacob, D. J., Logan, J. A., Koch, D., et al.: Radiative forcing from tropospheric ozone calculated with a unified chemistry-climate model, J. Geophys. Res., 104, $30153-$ $30172,1999$.

Poetzsch-Heffter, C., Liu, Q., Ruprecht, E., and Simmer, C: Effect of cloud types on the Earth radiation budget calculated with the ISCCP C1 dataset: methodology and initial results, J. Clim., 8, 4, 829-843, 1995.
Poppe, D., Zimmerman, J., Bauer, R., Brauers, T., Bruning, D., et al.: Comparison of measured $\mathrm{OH}$ concentrations with model calculations, J. Geophys. Res., 99, 16 633-16 642, 1994.

Prather, M., Gauss, M., Berntsen, T., Isaksen, I., Sunder, J., et al.: Fresh Air in the 21st Century?, Geophys., Res. Lett., 30, 2, 721 724, 2003.

Price, C., Penner, J., and Prather M.: $\mathrm{NO}_{\mathrm{x}}$ from lightning. 1. Global distribution based on lightning physics, J. Geophys. Res., 102, 5929-5941, 1997.

Prinn, R. G., Weiss, R. F., Miller, B. R., Huang, J., Alyea F. N., et al.: Atmospheric trends and lifetime of $\mathrm{CH}_{3} \mathrm{CCl}_{3}$ and global $\mathrm{OH}$ concentrations, Science, 269, 187-192, 1995.

Ramanathan, V., Callis L., Cess R., Hansen J., Isaksen, et al.: Climate-chemical interactions and effects of changing Atmospheric trace gases, Rev. Geophys., 25, 1441-1482, 1987.

Ramstein, G., Serafini-Le Treut Y., Le Treut, H., Forichon, M., and Joussaume S.: Cloud processes associated with past and future climate changes, Clim., Dynam., 14, 233-247, 1998.

Rind, D.: Latitudinal temperature gradients and climate change, J. Geophys. Res., 103, 5943-5971, 1998.

Roelofs, G. J. and Lelieveld J.: Tropospheric ozone simulation with a chemistry-general circulation model: Influence of higher hydrocarbon chemistry, J. Geophys. Res., 105, D18, 22697 22 712, 2000.

Russell, G. L., Miller, J. R., and Tsang, L. C.: Seasonal oceanic heat transports computed from an atmospheric model, Dyn. Atm. Oceans, 9, 253-271, 1985.

Shindell, D. T., Grenfell, J. L., Rind, D., Price, C., and Grewe, V.: Chemistry-climate interactions in the Goddard Institute for Space Studies general circulation model 1. Tropospheric chemistry model description and evaluation, J. Geophys. Res., 106, D8, 8047-8075, 2001.

Stevenson, D. S., Johnson, C. E., Collins, W. J., and Derwent., R. G., and Edwards, J. M.: Future estimates of tropospheric ozone radiative forcing and methane turnover - the impact of climate change, Geophys. Res. Lett., 27, 2073-2076, 2000.

Trainer, M., Parrish, D. D., and Buhr, M. P.: Correlation of ozone with $\mathrm{NO}_{\mathrm{y}}$ in photochemically aged air, J. Geophys. Res., 98, 2917-2932, 1993.

Wang, Y., Jacob, D. J., and Logan, J. A.: Global simulation of tropospheric $\mathrm{O}_{3}-\mathrm{NO}_{\mathrm{x}}$-hydrocarbon chemistry. 1. Model formulation. J. Geophys. Res., 103, 10713-10 725, 1998.

Wild, O., Zhu, X., and Prather, M. J.: Fast-J: Accurate simulation of in- and below-cloud photolysis in tropospheric chemical models, J. Atm. Chem., 37, 3, 245-282, 2000 